\title{
The Antitrust Liability of Labor Unions for Anticompetitive Litigation
}

\author{
Daralyn J. Durief and Mark A. Lemleył
}

Opposing permit applications on environmental or regulatory grounds is one strategy labor unions have used to eliminate competing nonunion contractors. Job owners who refuse to use union labor can find their projects blocked entirely or their costs increased significantly if their permits are challenged. The authors argue that union pursuit of litigation or permit interference against projects using nonunion contractors as a means of driving competitors out of business violates the antitrust laws. The primary objective of such union strategy is anticompetitive and bears no relation to the stated objectives of the threatened litigation or interference. While the labor exemption and Noerr-Pennington immunity limit the application of the antitrust laws to cases of this type, the Comment concludes that the unions can be held accountable for attempts to coerce market participants by monopolization or group boycotts.

\section{I \\ INTRODUCTION}

Union labor's share of the work force has decreased dramatically in recent years. ${ }^{1}$ In response to their declining influence, building-trades urions are becoming inore aggressive in their attempts to win project contracts. $^{2}$ These atteinpts are targeted not only at increasing inembership among workers but also at eliminating coinpeting nonunion contrac-

$\dagger$ B.A. 1988, Stanford University; M.A. 1989, University of California, Berkeley; J.D. 1992, Boalt Hall School of Law, University of California, Berkeley; Ph.D. candidate 1993, University of California, Berkeley.

$\ddagger$ Law clerk, Judge Dorothy W. Nelson, United States Court of Appeals for the Ninth Circuit. B.A. 1988, Stanford University; J.D. 1991, Boalt Hall School of Law, University of California, Berkeley.

We would like to thank Steve McCracken, who provided us with access to his research files, the staff of the California Law Review for their editorial assistance, and Professor Thonias M. Jorde, with whon we began this paper as a collaborative effort sone time ago. The usual disclaimers apply.

1. Matthew Herniann, Food Fight, ExPREss, Jan. 11, 1991, at 1, 10 ("In 1955 . . one out of every three workers in the United States was a union nreniber; today it's just one in six.").

2. See generally Toin Hunter \& Ray Foreman, Participation in the Permit Process: 1987 (unpublished manuscript on file with authors) (suniniary of key California construction-union permit litigation and lobbying efforts in 1987). 
tors. $^{3}$ One strategy that is gaining in popularity is to oppose permit applications involving contractors who do not use union labor, usually on environmental or regulatory grounds. This opposition can block the project entirely or increase project costs for those job owners who refuse to use union labor.

This union strategy has been largely successful in the limited areas in which it has been tried. ${ }^{4}$ Union interference in the building permit process through actual or threatened litigation or regulatory intervention can force inerit-sliop contractors ${ }^{5}$ out of business or cause job owners to hire union contractors exclusively. This union activity also raises the cost of using inerit-shop contractors and inakes it inore difficult for those contractors to compete. Our thesis is that a union strategy of pursuing litigation or permit interference against projects using nonunion contractors as a means of driving competitors out of business violates the antitrust laws.

Union conduct designed to increase the costs incurred by using nonunion contractors has anticoinpetitive consequences; to the extent such conduct facilitates a union inonopoly of the labor inarket, it necessarily restricts conpetition. There are several antitrust theories that could be brouglit to bear on this problein: monopolization, attenipted nonopolization, group boycotts, exclusive dealing, and cartelization. There are a number of lurdles to a successful antitrust suit, however. The first of these is the labor exemption to the antitrust laws, whicl protects certain union activities from antitrust challenges. The second is NoerrPennington immunity, ${ }^{6}$ which shields certain types of litigation and other petitioning activity from antitrust scrutiny.

Part II of this Comment provides an overview of the problen1, its scope, and the nature of the union conduct at issue. Part III explores various antitrust theories and their potential application to the union conduct. Part IV examines the labor exenuption, and Part V considers Noerr-Pennington immunity. Part VI concludes that although the labor exeinption imposes soine limits on atteinpts to hold unions liable for anticompetitive litigation, much union activity is actionable under the antitrust laws.

3. According to Robert A. Georgine, president of the AFL-CIO Building and Construction Trades Department, unions are "not only trying to make union contractors more competitive, but we are [now] making it more difficult for non-union contractors to get the job and for [them] to perform." William G. Krizan, Building Trades Plan Toyota-Type Fights, ENGineERiNG NewsREC., Feb. 5, 1987, at 42, available in LEXIS, Nexis Library, ENR File.

4. See infra Part II.

5. A merit-shop contractor is one whose employees are not organized into a union.

6. The Noerr-Pennington doctrine protects some petitioning activity directed at government agencies. The doctrine is named for Eastern Railroad Presidents Conference v. Noerr Motor Freight, Inc., 365 U.S. 127 (1961), and United Mine Workers v. Pennington, 381 U.S. 657 (1965). See infra Section V.A.1 (discussing the Noerr-Pennington doctrine in detail). 
II

The Scope of the Problem

\section{A. Union Interference with the Permit Process}

The union strategy at issue is to oppose the environmental and landuse permit applications of job owners who employ nonunion contractors. ${ }^{7}$ Such opposition can take the form of either litigation or intervention in federal, state, or local regulatory and zoning processes. Direct mtervention, lowever, is generally a last resort; unions as a rule do not sue job owners who agree to hire union contractors before a case is filed. The possibility of suit thus constitutes a threat-express or impliedagainst any job owner who contimues to use inerit-shop contractors. The primary objective of these threats, nainely the use of union contractors, often bears no relation to the stated objectives of the threatened litigation, which are generally to imitigate the environmental impact of the project. $^{8}$

While some environmental objections raised by the union to block construction permits arguably result in an improved environment, others do not. One example of union tactics that do not benefit the environment is the activity directed at USS-POSCO, a Korean developer. USSPOSCO's shipping operations have been challenged both by buildingtrades unions and the longshorenran's union in northern California. ${ }^{9}$ The longshoreman's union recently succeeded in laving substantial fines levied against USS-POSCO for noncoinpliance with environmental regulations. ${ }^{10}$ While the union's challenge was successful, USS-POSCO's noncomphiance was purely technical and did not endanger the environment. ${ }^{11}$ USS-POSCO has implied that the union was acting in retatiation for USS-POSCO's failure to use the longshoreman's umion in unloading its ships. ${ }^{12}$

In 1986, the AFL-CIO Building and Construction Trades Departnent used this type of litigation strategy against Ohbayashi Corporation, the Japanese construction manager for an $\$ 800$ million Toyota auto plant in Kentucky. Ohbayashi had initially used merit-shop contractors to build its plant, but eventually sigued project agreements

7. Union activities have focused on construction projects, perhaps because the nature of such projects requires continual regulatory oversight. See infra text accoinpanying notes 13-33 (review of recent union interference with nonunion construction projects).

8. Soine union hitigation may genuinely atteinpt to remedy environmental problems, but we do not address such efforts.

9. See infra text accoinpanying notes 10-12, 34-37.

10. Jeff Pelline, Bay Steelmaker Is Fined S1.6 Million, S.F. Chron., Apr. 23, 1991, at Cl.

11. Id. USS-POSCO was fined for not having the necessary permits, rather than for violations of air quality standards.

12. See id. USS-POSCO appears to have been using the United Steelworkers of Ainerica instead of the International Longshoreinan's Union. Id. 
with the union for the reniainder of the construction in the face of union challenges to the project's "political, economic, and environnental underpinnings." 13 Unions experimented with this method of attack as early as 1976, when a labor union and restaurant eniployer association atteinpted to block the construction of additional restaurants in a chain by opposing the grant of building permits by a city board. ${ }^{14}$

The building-trades unions in northern California appear to be engaged $\mathrm{n} 1$ a widespread, concerted effort, modeled on the successful attack against the Kentucky Toyota project, ${ }^{15}$ to hinder the issuance of environmental and land-use permits for construction projects using nonuinon labor. ${ }^{16}$ The unions have created a coniputer database of construction activity in the San Francisco Bay area, enabling them to challenge the permit applications of job owners enuploying inerit-shop contractors. ${ }^{17}$ The coniputer systen 1 is designed so that, in the union's words, "non-union contractors can be targeted area wide."18 Union documents indicate that the systein is intended to provide a mechanisin for challenging all nonunion projects on environmental and/or land-use grounds. Under this policy, " "[a]11 permits for known nonunion contractors would automatically be protested regardless of size or aniount of permit." "19

Union docunients suggest that the real motivation for filing the permit challenges is to delay the construction projects themselves rather than inerely to mitigate their environmental impact. After initially

13. Krizan, supra note 3, at 42 (reporting statement of Robert A. Georgine).

14. See Franchise Realty Interstate Corp. v. San Francisco Local Joint Executive Bd. of Culinary Workers, 542 F.2d 1076, 1078 (9th Cir. 1976), cert. denied, 430 U.S. 940 (1977). The Ninth Circuit found for the defendant unions on the antitrust claim on the basis of Noerr-Pennington immunity. Id. at 1080. The core holding of Franchise Realty, that the Noerr-Pennington doctrine's sham exception does not apply in such situations, was later overruled by the Supreme Court. See infra note 200 and accontpanying text. Interestingly, the court reached the Noerr-Pennington issue without even invoking the labor exception to the antitrust laws. The court apparently assuined that a umion could be held liable for anticompetitive hitigation if such litigation was shown to violate the antitrust laws.

15. See Krizan, supra note 3, at $\mathbf{4 2 .}$

16. This activity is an example of the type of union conduct at issue in this Comment.

17. San Francisco Crafts' Computer System to Monitor Area Construction Activity. Daily Lab. Rep. (BNA) No. 243, at A-1 (Dec. 18, 1986) [heremafter San Franeisco Crafts'].

18. Building Trades Councils Organizing Program Proposed, ORganized LAB., Feb. 24, 1986, at 1 [heremafter Organizing Program] (published by the Building and Construction Trades Council of San Francisco). The union strategy is premised in part on their claim that "[i]rresponsible corporations will seek to cut the costs of labor and the costs of environmental protection alike." Hunter \& Foreman, supra note 2, at 1. The unions cite no evidence to support their theory that merit-shop contractors are generally less compliant with environmental regulations than are union contractors. See id. Thus, it appears that contractors are targeted for environinental action on the basis of their labor policies rather than on the basis of any specific information on the environinental compliance of a given projeet. We have found no instance in which a union targeted a closed union shop for lack of envirouniental compliance.

19. Bay Area Unions Get Tough, ENGINEER1NG News-REc., Sept. 10, 1987, at 39, available in LEXIS, Nexis Library, ENR File (quoting Contra Costa County Building Trades business inanager Warren Jackinan). 
opposing all nonunion projects, unions "would then have to inake the decision of which projects are worthy of taking further action.... [W]ith proper investigation, this would uncover other reasons to delay projects, and delay is money to whoever applies for the permits." ${ }^{20}$ Stan Smith, secretary-treasurer for the San Francisco Building Trades Council, has said that in construction " "time is money. We will do anything we can to stop or delay a nonunion job." "21 These delays increase costs for nonunion contractors, and therefore give union contractors a competitive advantage, but they do not in themselves benefit the environment.

Moreover, the union activity goes beyond simple challenges to permit applications. According to the Buildings and Construction Trades Council of San Francisco:

Stopping or delaying permits at the source is only part of the solution. It would create a financial problem only for the owner, developer, or general contractor, but at that point, wonld have hittle or no effect on subcontractors .... [To reach subcontractors,] [p]re-job conferences wonld automatically be held with major projects. ... If we were able to react quick enough, the Council would inform contractors and unions when a low bidder was non-union prior to the signing of contracts. ${ }^{22}$

Armed with this information, unions could threaten interference with project permit apphications in order to preempt the signing of nonunion contracts.

The union strategy is thus two-pronged. The unions first approach job owners and contractors before permit apphications are filed to "encourage" them to use union labor. If that fails, the unions then oppose the permit apphications, thereby increasing the cost of using nonunion labor and making union labor relatively more cost-effective. Uinon contractors are reportedly "enthusiastic" about the program and have offered financial assistance, which the unions have dechined. ${ }^{23}$

Union docunients claim that the program will result in $\$ 300$ million of additional union labor income ni northern California alone. ${ }^{24}$ For example, in Shasta County, Califorma, the district construction union targeted the Signal Energy project, a 49.9 megawatt wood-burming power plant. ${ }^{25}$ Signal rejected a project agreenient and reportedly claimed that the use of union labor would cost an additional $\$ 6$ million. ${ }^{26}$ After an environmental impact statenient was prepared, the County Board of Supervisors approved the project. The union then filed a lawsuit chal-

20. Organizing Program, supra note 18 , at 1.

21. San Francisco Crafts', supra note 17, at A-1 (quoting Stan Smith).

22. Organizing Program, supra note 18, at 1.

23. San Francisco Crafts', supra note 17, at A-1.

24. See Hunter \& Foreman, supra note 2, at 2.

25. Id. at 3.

26. Id. 
lenging the Board's determination, appealed the issuance of the air permit to the Environmental Protection Agency (EPA), and filed a complaint with the California Energy Commission (CEC) alleging that the plant had a generating capacity of over 50 megawatts. ${ }^{27}$ The CEC ruled against the union, but the EPA appeal resulted in the EPA filing suit against Signal for violations of the Clean Air Act. ${ }^{28}$ Signal then entered into settlement negotiations, which resulted in an agreement that mcluded inodifications in air quality control estmiated by the union to cost as much as $\$ 6$ million-the same anount that Signal had claimed it would cost to use umon labor. ${ }^{29}$ On a subsequent project, Signal (now Wheelabrator Energy) discussed a project agreement with the buildingtrades union. ${ }^{30}$

The district building-trades umion also opposed a project consisting of nime cogeneration plants in Kern County, California. The union successfully appealed the Board of Zoning Adjustment's approval of the project to the City Council. ${ }^{31}$ Union documents state that the developer then approached the building-trades umion before commencing new permit applications and indicated that the plants would be built with union labor. ${ }^{32}$ The union has not challenged any of the subsequent permit applications.

These umion challenges have had repercussions on other projects in which no direct union action was taken. For exainple, the developers of a plant in Contra Costa County approached the union for a project agreement after hearing about the umion's activities on the Signal project and signed with several of the locals. ${ }^{33}$ Thus, the umions have been successful on both levels of their two-pronged attack: increasing costs for using merit-shop contractors and coercing job owners to sign project agreements with the unions.

\section{B. Responses to Union Activities}

The union hitigation strategy has not gone unchallenged. For example, USS-POSCO filed suit against the local building-trades unions in the Northern District of California. ${ }^{34}$ USS-POSCO had awarded a contract for a steel finishing plant to BE\&K Construction Conipany, a nonunion contractor from Alabama, which won the project with a bid $\$ 45$ million

27. Id.

28. 42 U.S.C. $\S \S 7401-7642$ (1988).

29. Hunter \& Foreman, supra note 2, at 3-4.

30. Id. at 4 .

31. The construction project had the support of local environmental groups. Id. at 5 .

32. Id.

33. Id. at 8 .

34. USS-POSCO Indus. v. Contra Costa Bldg. \& Constr. Trades Council, 1990-2 Trade Cas. (CCH) ๆ 69,095 (N.D. Cal. 1990). 
lower than the nearest union contractor's bid. ${ }^{35}$ After the union filed a number of suits against the project, USS-POSCO sued the umion on antitrust theories, alleging that the union had conibined and conspired with others to force nonunion contractors off the construction project. The urnons defended on the basis of the labor exemption to the antitrust laws. The court granted defendants' motion for partial summary judginent on the grounds that their activity was protected under the statutory labor exemption. ${ }^{36}$ That holding, however, is of questionable validity, ${ }^{37}$ and the continumg use of this strategy by unions nationwide makes further legal challenges inevitable.

Although antitrust hitigation to oppose union conduct is the focus of this Comment, three other legal arguments might be advanced to the same end. One such legal challenge could mvolve a civil Racketeering Influenced and Corrupt Organizations (RICO) suit against the union. RICO was enacted as Title IX of the Organized Crime Control Act of $1970 .{ }^{38}$ The statute prohibits a person from imvesting $\mathrm{m}$, acquiring, or conducting the affairs of an enterprise that is engaged in a pattern of racketeering activity. ${ }^{39}$ An enterprise is defined simply as a "group of persons associated together for a common purpose of engaging in a course of conduct." 40 In order to prove a pattern of racketeering activity, the plamtiff nuust show at least two acts that involve state felonies or acts mdictable under certain enumerated federal statutes. ${ }^{41}$

While it might be possible to characterize union activity as extortion or an attempt to force developers to enter into unlawful hot-cargo agreements, ${ }^{42}$ the success of a RICO claim agamst the unions is doubtful largely because it is difficult to find the requisite predicate felonies. Extortion requires threats or the use of physical force; ${ }^{43}$ if it did not, any labor umion that threatened to strike would be hable for extortion under RICO. And the Supreme Court has never held that violations of the antitrust statutes constitute predicate acts for RICO purposes. Thus, a

35. Krizan, supra note 3, at 42.

36. USS-POSCO, 1990-2 Trade Cas. (CCH) at 64,035; see infra text accompanying notes 159 61 (further discussion of USS-POSCO); cf. Franchise Realty Interstate Corp. v. San Francisco Local Joint Executive Bd. of Culinary Workers, 542 F.2d 1076 (9th Cir. 1976) (evaluating anticompetitive litigation strategy pursued by union under Noerr doctrine but not under labor exemption), cert. denied, 430 U.S. 940 (1977).

37. See infra notes 155-58 and accompanying text (discussing cases holding that the statutory exemption does not apply when a union conspires with nonumion forces).

38. 18 U.S.C. $\$ \S 1961-1968$ (1988).

39. Id. $\S 1962$.

40. United States v. Turkette, 452 U.S. 576,583 (1981).

41. 18 U.S.C. $\S 1961(1)$, (5) (1988).

42. "Hot-cargo" agreements stipulate "in advance that secondary boycotts will be acceptable under certain circumstances, and that employees may refuse to handle products of other employers who are involved in a labor dispute." 51 C.J.S. Labor Relations $\$ 250$ (1967) (footnotes omitted).

43. See, e.g., Cal. Penal Code $\S 518$ (West 1988). 
union might be able to violate the antitrust laws without incurring RICO hability, especially when, as is often the case, its veiled threats are so effective that more direct action is not required.

A second developers' strategy would be to seek Rule 11 sanctions against the complaints filed by the unions. ${ }^{44}$ There are two probleins with this strategy. First, because it is unclear whether an otherwise meritorious lawsuit can be part of an illegal pattern of activity, each individual complaint might pass a Rule 11 standard even if the pattern of conduct constituted harassment. ${ }^{45}$ Second, this approach requires that lawsuits be filed rather than merely threatened, and it cannot reach petitions directed at state and local government. Much union conduct involves such petitions. ${ }^{46}$

A third strategy would be to raise a common-law claim of tortious interference with business. A merit-shop contractor could clain that the union induced the job owner to breach its contract. ${ }^{47}$ The problein with this approach is simple: because the tort is based on state law, it is likely to be preeinpted by federal labor pohicy when apphed to unions. ${ }^{48}$ Moreover, this cause of action cannot reach those cases in which no contract is signed but the job owner hires union contractors on the basis of prior threats. Because the unions' conduct described in this Part is directed at the exclusion of competitors, we beheve that it is most logically evaluated under the federal antitrust laws. We attempt that task in the balance of this Comment.

\section{III}

\section{ANTITRUST VIOLATIONS}

The conduct described im Part II raises a nuniber of antitrust concerns. Section III.A will consider the effects of the union litigation in hight of the goals of the antitrust laws. Section III.B will describe different theories of antitrust hability that might be applied to the union activity. Section III.C will evaluate the probable success of the various antitrust theories on the facts described above.

Antitrust analysis im this case is complicated by the existence in

44. FED. R. CrV. P. 11 provides for sanctions against parties filing pleadings in bad faith in order to laarass, delay, or raise the cost of litigation.

45. See California Motor Transp. Co. v. Trucking Unlimited, 404 U.S. 508, 515-16 (1972) (requiring a "pattern" of baseless suits for antitrust liabihity); $c f$. infra notes 218-20 and accompanyimg text (considering whetler successful suits can nonetheless be shams).

46. See, e.g., supra text accompanying notes 31-32.

47. See, e.g., Imperial Ice Co. v. Rossier, 112 P.2d 631, 634 (Cal. 1941) (plaintiff bought business with covenant by seller not to compete and defendant induced seller to breach); RESTATEMENT (SECOND) OF TORTS $§ 766$ (1977) (one who intentionally and improperly causes a party to a contract not to perform may be liable to that party for damages).

48. See, eg., Textile Workers Union v. Lincoln Mills, 353 U.S. 448, 456-57 (1957) (discussing broad preemption power of the federal labor laws). 
most construction markets of at least three vertical levels: the workers (and their bargaining representative, the unions, when relevant), the contractors who employ the workers for specific tasks, and the job owners. This multilevel vertical market structure precludes a simplistic application of antitrust doctrine, which generally assumes either horizontal or two-tiered vertical markets. ${ }^{49}$ Evaluatimg antitrust harm im this context requires the evaluation of both the downstream effects of some activities that would traditionally be classified as horizontal and the effects of other activities on groups one level removed from the source of the harm.

\section{A. The Anticompetitive Consequences of Union Activity}

The goals of the umion activity described in the preceding Part are generally two-fold: to raise the wages of umion members and to mcrease union membership, which is equivalent to market share. ${ }^{50}$ In other words, the union seeks to monopolize the labor market-the sale of labor services to contractors. Monopoly itself is not illegal. ${ }^{51}$ Nonetheless, the antitrust laws are primarily concerned with monopoly and its economic effects, ${ }^{52}$ and conduct designed to achieve dominance in a market may violate section 2 of the Sherinan Act.

If monopoly were always illegal, virtually any effort to organize labor would run afoul of the antitrust laws. That is why union monopolies are protected by federal labor laws ${ }^{53}$ and the labor exemption to the

49. Citation to some of the Court's many boycott cases can do little more tlian give a sense of the issues witl whicl the antitrust laws liave been concerned. Nonetheless, for some instructive examples, see generally Brown Slioe Co. v. Umited States, 370 U.S. 294 (1962) (merger with horizontal and two-level vertical elements); Klor's, Inc. v. Broadway-Hale Stores, Inc., 359 U.S. 207 (1959) (boycott with similar strncture); Umited States v. American Tobacco Co., 221 U.S. 106 (1911) (first application of the antitrust laws to vertical restraints). Cf. ROBERT H. BoRK, THE ANTITRUST PARADOX: A POLICY AT WAR WTTH ITSELF 227-28 (1978) (questioning viability of vertical-restraint law).

50. Allen Bradley Co. v. Local Umion No. 3, Int'l Blıd. of Elec. Workers, 325 U.S. 797, 799 (1945); see also Thomas J. Campbell, Labor Law and Economics, 38 STAN. L. REv. 991, 1005-06 (1986) (labor laws are intended to promote union efforts at monopoly); Archibald Cox, Labor and the Antitrust Laws-A Preliminary Analysis, 104 U. PA. L. REv. 252, 254 (1955) (goal of labor unions is monopoly). See generally Gary Minda, The Common Law, Labor, and Antitrust, 11 INDUS. REL. L.J. 461 (1989) (noting conflict between goals of antitrust and labor laws).

51. United States v. Aluminum Co. of Am., 148 F.2d 416, 429 (2d Cir. 1945) (distinguishing monopoly achieved through competitive success from monopolization; antitrust law prohibits only the latter).

52. Section 2 of the Sherman Act, 15 U.S.C. $\$ 2$ (1988), prohibits monopolization or attempted unonopolization in any relevant market. The efficiency losses associated with monopoly are well documented and almost universally accepted. They will not be discussed in detail here. See generally BORK, supra note 49, at 107-15 (using consumer-welfare model to sliow that monopolies create inefficiencies); Douglas F. Greer, Industrial Organization and Public Policy 3134, 38-39 (1980) (explaining that efficiency requires "perfect competition"); RICHARD A. POSNER, ANTtTrust LAW-AN Economic PERSPECTIVE 8-22 (1976) (exploring the theory of monopoly and the justification for antitrust laws).

53. Campbell, supra note 50, at 1005-06. In addition, federal labor laws preempt the 
antitrust statutes. ${ }^{54}$ Thus, union monopolization of the labor market per se is exempt from antitrust scrutiny. Even so, such monopolization can have anticompetitive consequences-higher labor costs, lower labor supply, and a deadweight loss to society-similar to those stemming from traditional antitrust violations. ${ }^{55}$ Anticompetitive consequences can result not only froin union conduct sanctioned by the labor laws but also from other conduct that those laws were not designed to protect.

While the goal of monopolization is outside the purview of the antitrust laws, those laws properly are concerned with the means by whicl the union achieves market dommance. Group boycotts ${ }^{56}$ and exclusive dealing arrangements ${ }^{57}$ may violate the antitrust laws even if the resultant monopoly would not itself constitute a section 2 violation. ${ }^{58}$ The union's method of achieving control is to exclude its competitors from the labor and contracting markets. ${ }^{59}$ At one time, exclusion of competitors without nore would have been enough to trigger the operation of

application of state antitrust laws that do not take labor policy into account. See, e.g., Connell Constr. Co. v. Plumbers \& Steamfitters Local Union No. 100, 421 U.S. 616, 635-37 (1975) (state antitrust laws cannot be used to regulate union activity closely related to union's organizational goals); A \& D Supermarkets, Inc. v. United Food \& Coinmercial Workers, Local Union 880, 732 F. Supp. 770, 777-79 (N.D. Ohio 1989) (section 7 of the National Labor Relations Act (NLRA) precinpts state antitrust laws); C \& W Constr. Co. v. Brotherhood of Carpenters \& Joiners, Local 745, 687 F. Supp. 1453, 1470-71 (D. Haw. 1988) (relying on Connell to find that federal labor law preempts Hawan̈'s antitrust law); California State Council of Carpenters v. Associated Gen. Contractors, Inc., 404 F. Supp. 1067, 1072 (N.D. Cal. 1975) (federal law preempts state antitrust law; relying on Connell), rev'd on other grounds, 648 F.2d 527 (9th Cir. 1980), rev'd, 459 U.S. 519 (1983).

54. See infra Part IV (discussing statutory and nonstatutory labor exemptions).

55. Unions with power over industry wages may determine which firms with whieh automation policies survive; power over equipinent may limit the usage of efficient machinery that might reduce cost and prices; power over nuaterials and methods may determine the potential for beneficial imıvation; power over lours of work may determine when and where consumers may shop.

1 Phillip areeda \& Donald F. Turner, ANTttrust law: AN ANalysis of ANTitrust Principles ANd Their Application 189 (1978).

56. Northwest Wholesale Stationers, Inc. v. Pacific Stationery \& Printing Co., 472 U.S. 284, 297 (1985) (group boycotts generally subject to rule of reason); Klor's, Inc. v. Broadway-Hale Stores, Inc., 359 U.S. 207, 212 (1959) (boycotts illegal per se).

57. Tampa Elec. Co. v. Nashville Coal Co., 365 U.S. 320, 325-28 (1961) (exclusive-dealing arrangements illegal if they foreclose "substantial" competition); Standard Oil Co. v. United States, 337 U.S. 293, 301 (1949) (same).

58. See Clayton Act $\S 3,15$ U.S.C. $§ 14$ (1988) (exclusivc-dealing arrangements illegal).

59. Again, the vertical structure of the inarket may make the effects of these agreements seem confusing. For example, a union night force a job owner to agree to dcal exclusively with union contractors. Alternatively, union contractors coordinated by the union might boycott job owners who also use nonunion contractors, again in an atteinpt to force the job owner to liire only union contractors. While the union in both cases is attempting to influence the contractor market, rather than the labor market, it is doing so because increasing the inarket share of union contractors will increase its own market share, due to the ties between unions and union contractors in the labor inarket. 
the antitrust laws. ${ }^{60}$ Now, however, antitrust plaintiffs must show an injury to competition, not just to competitors. ${ }^{61}$

The union's activities affect conpetition in both the labor and contractor nuarkets. One goal of union organization is to increase wage rates-the price of labor input-through aggregating market power. ${ }^{62}$ Because union contractors generally pay higher wages than their nonunion counterparts, they are at a competitive disadvantage in bidding for contracts with job owners. As a result, market labor prices will rise to the level set by the umion monopolist when nonunion contractors are driven out of the market. ${ }^{63}$

Umion hitigation to drive price-conipetitive nonunion contractors out of the inarket can also have a number of adverse secondary effects on conipetition. First, by raismg the aggregate wage rate, the unions' actions raise barriers to entry in both the job-owner and contractor markets because projects will cost inore to conıplete. Raising barriers to entry makes market power in those downstream markets easier to maintani. Ohver Williamson concluded on the basis of an enipirical study that prevailing wage agreements between unions and employers had precisely this effect. ${ }^{64}$

Second, union contractors are currently constramed by the price

60. See Brown Shoe Co. v. United States, 370 U.S. 294, 344 (1962) (noting purpose of antitrust laws to protect competition by protecting small competitors).

61. While a discussion of the antitrust injury doctrine is beyond the scope of this Comment, it is sufficient to note that cases such as Atlantic Richfield Co. v. USA Petroleum Co., 495 U.S. 328, 334-35 (1990); Cargill, Inc. v. Monfort, Inc., 479 U.S. 104, 113 (1986); and Brunswick Corp. v. Pueblo Bowl-O-Mat, Inc., 429 U.S. 477, 489 (1977) established a requirement that a private antitrust plaintiff demonstrate mjury to competition in order to have standing to bring a complaint.

62. At the present time throughout our jurisdiction, we are controlling less than $50 \%$ of the total work. If we are willing to spend the noney and put our proven programs to work everywhere, we will have a blueprint that will enable us to be doing $80 \%$ plus of the work in three to five years.

Letter from Thomas J. Hunter, Business Manager, Northern California \& Northern Nevada Pipe Trades District Council No. 51, to members (Feb. 21, 1990) (on file with authors); see also Campbell, supra note 50, at 1005-06 (goal of umions in general is to increase wage rates by aggregatimg power in the labor market).

63. Unions contend that it is the merit-shop contractors who are undercutting "fair" competition, presumably by imposing some externality (such as excessively low wage rates) on society. We have two problems with this argument. First, it assumes that competition is not the best. way to set market prices. While this might be the case, in our free-narket economy there ought to be some burden on the nmion contractors to prove the existence of that externality in order to justify deviating from competition. Had Congress intended to supplant the free-market economy entirely in the labor context, it could have passed closed-shop laws. Second, even if competition is not efficient here, it is either naive or dismgenuous to suggest that a private monopoly is the answer. Only if we trnst an interested party-the union-to measure the size of that externality accurately and compensate appropriately should we favor union rather than government regulation. There is certainly no evidence that groundless union lawsuits will accomplish this result.

64. Oliver E. Willianson, Wage Rates as a Barrier to Entry: The Pennington Case in Perspective, 82 Q.J. Econ. 85, 112 (1968). Such agreements were condemned by the Supreme Court in United Mine Workers v. Penmington, 381 U.S. 657, 665 (1965). 
conipetition of their nonunion counterparts. If those nonunion contractors are forced to hire union labor at a higher wage in order to stay in the market, their costs go up. Union contractors gain power over price by raising their rivals' costs. Krattenmaker and Salop have suggested that "in carefully defined circumstances, certain firms can attain nonopoly power by making arrangements with their supphers that place their con1petitors at a cost disadvantage."65 Conipetition will suffer regardless of whether nonopoly power is attained because unions will obtain power over price equal to the niargin between union and nonunion wage rates. ${ }^{66}$

Finially, a union's exclusionary activities can, purposefully or accidentally, facilitate a cartel in the contracting niarket. This can occur in one of two ways. First, if a union is successful in excluding nonunion contractors from the market, the nuniber of firms in the contracting inarket will decrease. Because the likely success of a cartel is generally mversely related to the number of firms in an industry, ${ }^{67}$ this alone night facilitate the formation of a downstreain cartel. ${ }^{68}$ Second, a union can be an effective coordinator for a cartel. If successful in excluding nonunion contractors, the union provides all labor to the contractors and thus controls the supply of a vital input. Therefore, it controls the ability of each firm to supply contracting services. The union also controls prices directly, by setting wages. The union is therefore well suited to police a cartel. This theory is similar to what Krattenniaker and Salop have called the "cartel ringinaster" theory. ${ }^{69}$ While inerely inaking a cartel more likely is not an antitrust violation, coordinating one is. ${ }^{70}$

65. Thomas G. Krattenmaker \& Steven C. Salop, Anticompetitive Exclusion: Raising Rivals' Costs to Achieve Power over Price, 96 YALE L.J. 209, 214 (1986).

66. For this reason, we disagree with Krattenmaker and Salop when they say that "claims of anticompetitive exclusion should be judged according to whether the challenged practice places rival competitors at a cost disadvantage sufficient to allow the defendant firm to exercise monopoly power." Id. at 214 (emphasis added). The exclusion hurts competition regardless of the size of the price increase. Because group boycotts should be judged under the rule of reason, however, see infra text accompanying notes 108-10, the size of the price imcrease will be relevant in balancing the injury to competition against any procompetitive justifications for the boycott.

67. Because cartels depend for their success on convincing participants to reduce output and increase price, each member has an incentive to cheat on the cartel by secretly increasing output or decreasing price. See GREER, supra note 52, at 274 (price shadimg is not uncommon). A successful cartel must therefore have an effective policing mechanism. See POSNER, supra note 52, at 39-40 (describing the "machinery of cartelization"). For obvious reasons, it is easier to police a inarket with a few large competitors than one made up of numerous small firms.

68. Krattenmaker \& Salop have called this the "Frankenstein inonster" theory, which seeins appropriate in that the creature (the cartel) might be beyond the control of its "master" (the union). Krattenmaker \& Salop, supra note 65 , at 240-42.

69. Id. at $238-40,260-62$.

70. Interstate Circuit, Inc. v. United States, 306 U.S. 208, 232 (1939) (agreements between film distributors and theater owners mandating minimum admission prices violate the Sherman Act); United States v. Terminal R.R. Ass'n, 224 U.S. 383, 409 (1912) (agreetnent forcing a nonparty coinpetitor to use resources over which party has monopoly violates the Sherman Act). Interstate Circuit has been much criticized by commentators, see 6 Phillip E. AREedA, ANTITRust LAw: 
In short, regardless of whether it is protected, union activity of the type described here can have significant anticompetitive consequences. In the next Part, we consider how the antitrust laws are likely to treat such conduct.

\section{B. Antitrust Theories}

\section{Monopolization}

Section 2 of the Sherman Act prohibits both nonopolization and attempted monopolization. ${ }^{71}$ Monopolization requires proof of two elements: market power and anticonipetitive conduct designed to attain or nuaintain that power. ${ }^{72}$ Determination of nuarket power, and by implication narket definition, can require a case-by-case factual inquiry that has been the subject of extensive commentary elsewhere. ${ }^{73}$ It is not helpful to discuss it further here, except to note that the northern California building-trades union's nuarket share of $50 \%$, which it hopes to increase to $80 \%$ through the hitigation in question, ${ }^{74}$ probably constitutes inarket power sufficient to invoke the rule of reason. ${ }^{75}$

A variety of acts can constitute "anticonpetitive conduct," including several, such as gronp boycotts and exclusive-dealing arrangements, which nuay theniselves be antitrust violations. A number of courts and commentators have concluded that baseless hitigation of the type in which unions have engaged can itself be anticompetitive conduct. ${ }^{76} \mathrm{We}$ discuss below each of the types of anticompetitive conduct in which a nnion imght engage. ${ }^{77}$

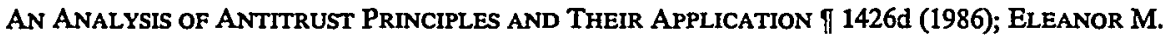
FoX \& Lawrence A. Sullivan, CASES AND Materiais on ANTITRust 456-57 (1989), but largely on the grounds that the Court there condemned interdependent as well as collusive pricing. If it is clear that a central party did orchestrate a cartel, liability seems clear. We discuss Interstate Circuit in more detail infra text accompanying notes 116-25.

71. 15 U.S.C. $\$ 2$ (1988).

72. See supra note 51 .

73. See, e.g., Umited States v. Philadelphia Nat'1 Bank, 374 U.S. 321,364 (1963) (stating that a $30 \%$ market share represents a clear threat of undue concentration). See generally ANTITRUST Division, U.S. DeP'T of Justice, Merger Guidelines 3-9 (1984) (outluning guidelines the Department of Justice uses to determine markets in analyzing inergers); Robert G. Harris \& Thomas M. Jorde, Antitrust Market Definition: An Integrated Approach, 72 CALIF. L. REv. 1 (1984) (arguing that market definition is a critical component of antitrust law application).

74. See supra note 62 .

75. Antitrust violations are of two types: actions that are illegal per se and actions judged under the rule of reason. The former are automatically illegal witlout regard to their effect iu a particular case, while the competitive effects of the latter are evaluated on a case-by-case basis. See Northwest Wholesale Stationers, Inc. v. Pacific Stationery \& Printing Co., 472 U.S. 284, 296-97 (1985).

76. See infra note 126.

77. See infra Section III.B.2 (group boycotts); Section III.B.3 (exclusive-dealing arrangements); Section III.B.4 (cartel-facilitation theory); Section III.B.5 (anticompetitive litigation). 
Even if a umion does not possess market power, it may be liable for attempting to monopolize. Attempted monopolization requires three elements: conduct, intent to inonopolize, and a dangerous probability of success. ${ }^{78}$ The conduct analysis is identical to that undertaken in monopolization claims. ${ }^{79}$ Intent to inonopolize is again a factual issue, but it is important to note that unions always "mtend" to monopolize the labor market. Indeed, that is precisely what the labor laws protect. ${ }^{80}$ According to some courts, mtent to monopolize can also be inferred from evidence of illegal conduct. ${ }^{81}$

Finally, the requirement of dangerous probability of success seems to approximate the market-power test of monopolization. ${ }^{82}$ However, there is one important differencc: it tests ability to acquire market power in the future, not just current market power. Nonetlieless, as Professors Fox and Sullivan have imdicated, current market power will be an inportant part of that test. ${ }^{83}$ Market sliares of $50 \%$, and certainly $80 \%$, should meet it.

The Nimth Circuit has rejected dangerous probability of success as an independent standard for evaluating inonopolization claims. In that Circuit, dangerous probability of success can be inferred froin proof of conduct and intent. ${ }^{84}$ Since intent may be inferred froin illegal con-

78. Fox \& SullivaN, supra note 70, at 162; see Swift \& Co. v. United States, 196 U.S. 375, 396 (1905) (when anticompetitive conduct is coupled with an intent to monopolize, there is a violation of antitrust laws).

79. See supra text accompanying notes 76-77.

80. Campbell, supra note 50, at $1005-06$ ("The [labor] union is a statutorily permitted monopoly of an imput good, imtended to eliminate competition in the labor market."); see infra Part IV (discussing the statutory and nonstatutory labor exemptions).

81. Handgards, Inc. v. Ethicon, Inc., 743 F.2d 1282, 1293 (9th Cir. 1984) ("An antitrust plaintiff can establish the existence of specific intent not only by direct evidence of unlawful design, but by circumstantial evidence of illegal conduct."), cert. denied, 469 U.S. 1190 (1985); see also William Inglis \& Sons Baking Co. v. ITT Continental Baking Co., 668 F.2d 1014, 1027-28 (9th Cir. 1981) (only conduct that itself serves as the basis for antitrust claims may support inference of intent), cert. denied, 459 U.S. 825 (1982).

82. There is a close relationship between the typical attempt case and the typical monopolization case. To prove dangerous probability of success in an attempt case, the plaintiff normally must prove that the defendant already has considerable power. ... [T] difference between attempt to monopolize and inonopolization is shadowy. Often, it is mainly a matter of the degree of market power that must be shown.

Fox \& SuliIVAN, supra note 70, at 162.

83. Id.

84. The state of the law in the Ninth Circuit is, to say the least, unclear. See Northrop Corp. v. McDonnell Douglas Corp., 705 F.2d 1030, $1057-58$ (9th Cir.) (noting conflict over dangerousprobability test, but refusing to decide whether proof of probability is required), cert. denied, 464 U.S. 849 (1983). Compare Lessig v. Tidewater Oil Co., 327 F.2d 459, 474 (9th Cir.) (rejecting dangerous probability of success as an element of attempted inonopolization), cert. denied, 377 U.S. 993 (1964) with Blair Foods, Inc. v. Ranchers Cotton Oil, 610 F.2d 665, 669 (9th Cir. 1980) (dangerous probability of success is relevant but "not indispensable") and with William Inglis \& Sons, 668 F.2d at 1029-30 and Brownlee v. Applied Biosystems, Inc., 1989-1 Trade Cas. (CCH) १ 68,425 , at 60,339 (N.D. Cal. 1989) (both holding that dangerous probability of success is a requirement, but that it can be inferred from evidence of intent and conduct) and with United States 
duct, ${ }^{85}$ conduct alone is enough to establish attempted monopolization. The Ninth Circuit rule is unwise. It miglit make sense to infer mtent from conduct, especially when, as in the case of bad-faith hitigation, anticompetitive motive is itself an element of that conduct. ${ }^{86}$ There is no reason to assume, however, that a defendant is likely to succeed im monopolizing the market merely because he has tried. The dangerousprobability requirement serves the salutary function of limiting antitrust liability to defendants whose actions have had or may have significant anticompetitive consequences. Under our preferred approacl, therefore, a umion can be hable for monopolization, or attempt, if it has actual or potential market power and lias engaged in anticompetitive conduct. This standard seems likely to reach many, if not most, umons involved in the hitigation practices at issue here. ${ }^{87}$

\section{Group Boycotts}

A group boycott or concerted refusal to deal ${ }^{88}$ violates section 1 of the Sherman Act. Exactly what constitutes a group boycott is, as the Supreme Court lias noted, "far from certain." 89 The category is potentially very broad, mcludimg almost every agreement between two or more parties to refuse to buy from or sell to another party. The parties can be im a vertical or horizontal relationship with each other and with the party they are boycotting. ${ }^{90}$ In either case, the Supreme Court has made it clear that a group boycott or refusal to deal can be an antitrust violation. ${ }^{91}$

v. Syufy Enters., 903 F.2d 659, 671 n.21 (9th Cir. 1990) ("the attempted monopolization claim fails because the government cannot show that there was a dangerous probability" of success; defendant's market share reached $100 \%$ at one point).

85. See cases cited supra note 81 .

86. Some courts have limited inferences of intent to conduct showing "bad faith." See, e.g., CVD, Inc. v. Raytheon Co., 769 F.2d 842, 851 (1st Cir. 1985) ("[A] specific intent to monopolize or restrain competition can often be inferred from a finding of bad faith."), cert. denied, 475 U.S. 1016 (1986); Handgards, Inc. v. Ethicon, Inc., 601 F.2d 986, 993 n.13 (9th Cir. 1979) ("[P]rosecution of a bad faith infringement action likely would constitute an attempt to monopolize violative of section 2."), cert. denied, 444 U.S. 1025 (1980).

87. See supra Section II.A.

88. Courts and commentators almost invariably use these terms interchangeably. See, e.g., Northwest Wholesale Stationers, Inc. v. Pacific Stationery \& Printing Co., 472 U.S. 284, 293 (1985); see also cases and commentators cited infra notes 90-110.

89. Northwest Wholesale, 472 U.S. at 294.

90. See, e.g., Klor's, Inc. v. Broadway-Hale Stores, Inc., 359 U.S. 207, 212-13 (1959) (condemning group boycott containing both vertical and horizontal elenents among boycotters and between boycotters and their target); Fashion Originators' Guild, Inc. v. FTC, 312 U.S. 457, 466-68 (1941) (boycotts of downstream firms illegal). In a classic understateinent, the Supreme Court noted that concerted refusals to deal "are not a unitary phenomenon." St. Paul Fire \& Marine İns. Co. v. Barry, 438 U.S. 531, 543 (1978) (quoting Phillip AreedA, ANTtTrust ANalysis 381 (2d ed. 1974)).

91. E.g., FTC v. Superior Court Trial Lawyers Ass'n, 493 U.S. 411, 434-36 (1990) (lawyers violated antitrust law by organizing and participating in boycott aimed at forciug increased 
The union actions at issue here seen to fall within the definition of a group boycott. There are two types of boycotts at work here-a horizontal one and a vertical one. A horizontal boycott occurs when the union agrees with union contractors to boycott job owners who use or plan to use nonunion contractors. This pressures job owners to use exclusively union contractors by foreclosing their supply of labor if they do not. The agreenent between the boycotters is vertical, but the boycott operates against a horizontal conipetitor: its effect is to force the job owner to cut off nonunion contractors. In the second type of boycott, the union agrees directly with the job owner that the job owner will boycott nonunion contractors. This boycott is vertical: the squeeze comes fron the contractors' downstrean purchaser, the job owner. ${ }^{92}$

As with organizing activity itself, many activities central to union power, including strikes and related boycotts, seen to fall within the broad reach of the Sherman Act's prohibition of group boycotts. ${ }^{93}$ As a result, group-boycott claims have frequently been used to attack union activities under the antitrust laws, sometimes successfully. ${ }^{94}$

compensation); Northwest Wholesale, 472 U.S. at 293-94 (group boycotts are anticompetitive activity that merit per se condemnation); Radiant Burners, Inc. v. Pcoples Gas Light \& Coke Co., 364 U.S. 656, 659-60 (1961) (refusal to provide gas for plaintiffs was antitrust violation); United States v. Women's Sportswear Mfrs. Ass'n, 336 U.S. 460, 463 (1949) (agreement to hire contractors with certain qualifications had intent and effect of impermissibly restricting competition and controlling prices and market); Fashion Originators' Guild, 312 U.S. at 466.68 (boycotts of downstream firms illegal); Paramount Famous Lasky Corp. v. United States, 282 U.S. 30, 41-42 (1930) (agreements among film distributors and theater owners constituted illegal restraint on commerce).

92. The job owners are almost certainly being coerced into this "agreement," which will raise their imput costs. This does not affeet the antitrust status of the boycott. It is well established that a party may be hable for "combining with" an unwilling participant. See, e.g., Perma Life Mufflers, Inc. v. International Parts Corp., 392 U.S. 134, 141-42 (1968) (illegal conspiracy possible when petitioner unwillingly complied with restrictive franchise agreement).

93. Generally, strikes and threats directed at an employer are protected by the labor laws. See 29 U.S.C. $\$ 52$ (strikes not prohibited). But see United States v. Women's Sportswear Mfrs. Ass'n, 336 U.S. 460, 463-64 (1949) (union closed-shop agreement violates antitrust laws). The closed shop in Women's Sportswear was not entirely union-based. The jobber agrced to deal only witl firms who were both unionized and belonged to a trade association. Id. at 462 . In addition, there was some indication that the urion requirement was a sliam designed to shield the agreement from antitrust liability. Id. This case is likely limited to its factual context. In any event, the broad prohibition on labor activity one could read into it has not been adopted by the Court in subsequent cases.

94. Cf. Associated Gen. Contractors, Inc. v. California State Council of Carpenters, 459 U.S. 519, 528-29 (1983) (antitrust claim against similar acts by nonunion contractors was viable, but union lacked standing as a plaintiff); International Longshoreman's Ass'n v. Allied Int'l Inc., 456 U.S. 212, 222-24 (1982) (political boycott against Soviet products was illegal secondary boycott under the NLRA). Compare Connell Constr. Co. v. Plumbers \& Steamfitters Local Union No. 100, 421 U.S. 616 (1975) (union's coercion of job owners to deal exclusively with union subcontractors is an antitrust violation); Allen Bradley Co. v. Local Union No. 3, Int'l Bhd. of Elec. Workers, 325 U.S. 797 (1945) (union combimation with employers to assist them in monopolizing market violates antitrust laws); Larry V. Muko, Inc. v. Southwestern Pa. Bldg. \& Constr. Trades Council, 609 F.2d 1368, 1376 (3d Cir. 1979) (agreement between nnion and job owner to hire only union contractors stated antitrust claim for conspiracy), cert. denied, 459 U.S. 916 (1982); Commerce Tankers Corp. v. National Maritime Union, 553 F.2d 793, 801-02 (2d Cir.) (group boycott by union could violate 
How such claims are to be evaluated on their merits-whether under the rule of reason or a rule of per se illegality-is far from clear. Indeed, Professor Sullivan has gone so far as to claim that "there is more confusion about the scope and operation of the per se rule against group boycotts than in reference to any other aspect of the per se doctrine."95 Commentators have discussed the issue exhaustively. ${ }^{96}$ The Supreme Court has set forth a variety of often conflicting pronouncements on the question. Early court decisions seem to establish that group boycotts are illegal per se. ${ }^{97}$ Even during this period, however, the Court backed off

Sherman Act), cert. denied, 434 U.S. 923 (1977); Imperial Constr. Mgmt. Corp. v. Laborers Int'1 Union, Local 96, 729 F. Supp. 1199, 1208-17 (N.D. Ill. 1990) (union picketing of nonunion construction company raised substantial antitrust claim for trial); A \& D Supermarkets, Inc. v. United Food \& Commercial Workers, Local Union 880, 732 F. Supp. 770, $772-77$ (N.D. Ohio 1989) (union's agreement with union grocery stores requiring picketing of nouunion stores violated antitrust laws); C \& W Constr. Co. v. Brotherhood of Carpenters \& Joiners, Local 745, 687 F. Supp. 1453, 1461-65 (D. Haw. 1988) (union picketing of suppliers of nonunion contractor to force contractor to go union could violate the antitrust laws); and Altenose Constr. Co. v. Atlantic, Cape May, \& Parts of Burlington, Ocean \& Cumberland Counties Bldg. Trades Council, 493 F. Supp. 1181, 1190-91 (D.N.J. 1980) (allegedly coerced union agreement with suppliers of nonunion contractor stated monopolization claim) with United Mine Workers v. Pennington, 381 U.S. 657, $664-65,669-70$ (1965) (union agreenient to seek prevailing wage statute is subjeet to antitrust laws, but is protected under Noerr); Apex Hosiery Co. v. Leader, 310 U.S. 469, 500-01 (1940) (union strike does not violate antitrust laws unless it affects product prices); and USS-POSCO Indus. v. Contra Costa Bldg. \& Constr. Trades Council, 1990-2 Trade Cas. (CCH) If 69,095 (N.D. Cal. 1990) (union threats and petitions aimed at forcing construction contractor to go union constituted protected activity).

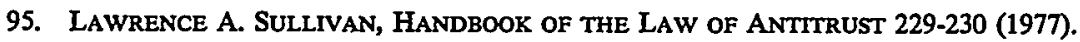

96. See, e.g., Charles F. Barber, Refusals to Deal Under the Federal Antitrust Laws, 103 U. PA. L. REv. 847, 872-79 (1955) (group boycott should be analyzed in the context of its operation); Milton Handler, Recent Developments in Antitrust Law: 1958-59, 59 CoLUM. L. REv. 843, 862, 865 (1959) (group boycotts are per se unlawful); Allen C. Horsley, Per Se Illegality and Concerted Refusals to Deal, 13 B.C. InDus. \& CoM. L. REv. 484 (1972) (rule of reason should be applied in cases where primary intent or major effeet is not anticompetitive); Ann G. McCormick, Group Boycotts-PerSe or Not Per Se, That Is the Question, 7 SETon HALL L. REv. 703 (1976) (advocating strict application of per se rule); James A. Rahl, Per Se Rules and Boycotts Under the Sherman Act: Some Reflections on the Klor's Case, 45 VA. L. REv. 1165, $1169-70$ (1959) (noting that even after Klor's it is not clear what the rule on boycotts is); Edward A. Wooley, Is a Boycott a Per Se Violation of the Antitrust Laws?, 27 RUTGERS L. REV. 773 (1974) (arguing Supreme Court should reconsider its per se rule); Comment, Concerted Refusals to Deal A Per Se Violation of the Sherman Act?, 51 Nw. U. L. REv. 628 (1956) (boycotts should be illegal per se); H. Robert Switzer, Comment, $A$ ReExamination of the Boycott Per Se Rule in Antitrust Law, 48 TEMP. L.Q. 126, 146-48 (1974) (boycotts should be evaluated under a two-step analysis: purpose and effeet); Note, Antitrust: Trade Association's Refusal to Deal Held a Per Se Violation, 1961 DUKE L.J. 302, 307 (per se presumption inconsistent with actual social and economic consequences of boycotts).

97. See, e.g., United States v. General Motors Corp., 384 U.S. 127, 145-47 (1966) (elimination of access to narket for discount car retailers per se violation); Radiant Burners, Inc. v. Peoples Gas Light \& Coke Co., 364 U.S. 656, 659-60 (1961) (refusal to supply gas to petitioner was per se invalid); Klor's, Inc. v. Broadway-Hale Stores, Inc., 359 U.S. 207, 212 (1959) (sale of houseliold appliances by inanufacturers and distributors at discriminatory prices and highly unfavorable terms per se invalid); Northern Pac. R.R. v. United States, 356 U.S. 1, 5 (1958) (railroad's preferential routing agreements per se invalid); United States v. Colunibia Steel Co., 334 U.S. 495, 522-23 (1948) (noting that group boycotts are illegal per se); Fashion Origmators' Guild, Inc. v. FTC, 312 U.S. 
froin the per se rule in two separate instances. In Silver v. New York Stock Exchange ${ }^{98}$ the Court refused to invalidate New York Stock Exchange rules limiting membership, concluding that the per se rule did not apply in heavily regulated contexts such as stock exchanges. ${ }^{99}$ In Apex Hosiery Co. v. Leader ${ }^{100}$ the Court seenned to establisli the rule of reason as the test for group boycotts. The Court stated that a group boycott must affect prices im order to be illegal under section $1 .{ }^{101}$ Significantly, the Court in Klor's, Inc. v. Broadway-Hale Stores, Inc. distinguished Apex Hosiery on the grounds that "the defendant in that case was a labor umion," 102 apparently implying that tlie rule of reason would govern in labor cases even tliougl the per se rule governed elsewhere.

More recently, the Court has followed the suggestion of commentators ${ }^{103}$ and soine courts ${ }^{104}$ and rejected the autonatic application of the per se rule to group boycotts. In Northwest Wholesale Stationers, Inc. $v$. Pacific Stationery \& Printing Co. the Court held that the rule of reason applied to a group-boycott claim brouglit by a competitor excluded from ineinbership in a wholesale purchasing cooperative. ${ }^{105}$ The Court claimed that the per se rule is still appropriate, but only when "the likelilood of anticompetitive effects is clear and the possibility of countervailing procompetitive effects is remote."106 This occurs priunarily when the boycott cuts off access to an essential facility and "tlee boycotting firms possessed a dommant position in the relevant inarket." ${ }^{107}$

A per se rule that applies only whien a defendant has inarket power and cannot slow procoinpetitive effects is no per se rule at all. The Court's test is largely indistinguisliable froin the rule of reason. ${ }^{108}$ The

457, 467-68 (1941) (garment and textile manufacturers' refusal to sell to manufacturers or retailers who dealt in copies of the designs per se invalid); see also Handler, supra note 96, at 865 (Klor's makes per se rulc clear). But see McCormick, supra note 96, at 708-36 (arguing that the Court never actually held group boycotts illegal per se).

98. 373 U.S. 341 (1963).

99. Id. at $366-67$.

100. 310 U.S. 469 (1940).

101. Id. at 499-501.

102. Klor's Inc. v. Broadway-Hale Stores, Inc., 359 U.S. 207, 213 n.7 (1959).

103. See Rahl, supra note 96, at 1169-70; Switzer, supra note 96, at 146-48; Note, supra note 96, at 307. All these commentators have suggested using versions of the rule of reason to evaluate group boycotts. $C f$. Barber, supra note 96 , at 877 (suggesting that legality of group boycotts should turn on whether the boycott was intended to restrict competition or was merely incidental to a legal counbination).

104. See, e.g., Counmerce Tankers Corp. v. National Maritime Union, 553 F.2d 793, 802 (2d Cir.) (questioning the wisdom of applying the per se rule to nonexempt labor activity), cert. denied, 434 U.S. 923 (1977).

105. 472 U.S. 284,298 (1985).

106. Id. at 294.

107. Id.; see also National Collegiate Athletic Ass'n v. Board of Regents, 468 U.S. 85, 104 n.26 (1984) ("Per se rules may require considerable inquiry into inarket conditions before the evidence justifies a presumption of anticonpetitive conduct.").

108. In Rickards v. Canine Eye Registration Foundation, 783 F.2d 1329, 1332-33 (9th Cir.), 
Court's move towards the rule of reason seens appropriate in the case of group boycotts. First, a per se rule could chill efficient or otherwisedesirable conduct. Second, legitimate or independent conduct could in some cases be recast by plaintiffs as a group boycott in order to take advantage of the per se rule. When such a danger is present, the rule of reason is an appropriate device to filter out such cases. ${ }^{109}$ Indeed, the Court recently has faced several cases in which a rigorous application of section 1 would condemn combinations that are either efficient or necessary because of inarket structure. ${ }^{110}$ In each case, the Court upheld the legality of the challenged activity. These concerns, combined with the issues of labor pohicy noted above, counsel against the use of a per se rule in evaluating group boycotts. Umion conduct of the type described here should be subject to antitrust scrutiny under the rule of reason.

\section{Exclusive Dealing Arrangements}

Section 3 of the Clayton Act prohibits exclusive-dealing arrangeinents that substantially reduce coinpetition. ${ }^{111}$ The Court has interpreted this qualifying clause as requiring varying degrees of market power, but usually less than would be required to prove

cert. denied, 479 U.S. 851 (1986), the Ninth Circuit concluded that "a per se analysis is inappropriate" in a group-boycott case under Northwest Wholesale, but affirmed the finding of a section 1 violation under the rule of reason. Elsewhere, one of the authors has suggested that requiring proof of market power abolishes the per se rule altogether. See Thomas M. Jorde \& Mark A. Leinley, Summary Judgement in Antitrust Cases: Understanding Monsanto and Matsushita, 36 ANTITRUST BuLL. 271, 309 n.127 (1991) ("[T] he market power requirements in tying and boycotts [take] these cases out of the realm of the per se rule."); see also Mark A. Lemley, Comment, The Economic Irrationality of the Patent Misuse Doctrine, 78 CAL1F. L. REv. 1599, 1624-25 (1990) (drawing similar conclusions froin the Court's tying-arrangements jurisprudence).

One recent Supreme Court decision suggests in dictum that the per se rule has continuing vitality. See Associated Gen. Contractors, Inc. v. California State Council of Carpenters, 459 U.S. 519,528 (1983) ("Coercive activity that prevents its victims from inaking free choices between market alternatives is inherently destructive of competitive conditions and inay be condemned even without proof of its actual market effect."). The case was decided on standing grounds, so the Court did not give full consideration to the issue. Id. at 545-46. Northwest Wholesale, decided two years later, gives the opposite impression and appears to be the direction in which antitrust jurisprudence is moving. See supra text accompanying notes 105-07.

109. Cf. Jorde \& Lemley, supra note 108, at $298-99$ (reading the Court's Matsushita opinion as responding to similar concerns by heighteming summary judgment standards).

110. See, e.g., National Collegiate Athletic Ass'n v. Board of Regents, 468 U.S. 85, 101-02 (1984) (intercollegiate association necessary to contract efficiently for media coverage of sports events); Broadcast Music, Inc. v. Columbia Broadcasting Sys., 441 U.S. 1, 20 (1979) (blanket licenses facilitate integration of sales and enforcement agaiust copyright infringeinent).

111. 15 U.S.C. $\$ 14$ (1988). Exclusive-dealing arrangements may also violate section 1 of the Sherman Act, see Standard Oil Co. v. Umited States, 337 U.S. 293, 314 (1949), section 2 of the Sherman Act, see Cass Student Advertising, Inc. v. National Educ. Advertising Servs., Inc., 537 F.2d 282, 283 (7th Cir. 1976), and section 5 of the FTC Act, Adolph Coors Co. v. FTC, 497 F.2d 1178, 1186-87 (10th Cir. 1974), cert. denied, 419 U.S. 1105 (1975); L.G. Balfour Co. v. FTC, 442 F.2d 1, 19-20 (7th Cir. 1971). 
monopolization. ${ }^{112}$

Characterizing the union activities here as exclusivc-dealing arrangements is somewliat problematic. Agreements between the union and umion contractors are exclusive-dealing arrangements only in the sense that all collective-bargaining agrecments are exclusive. But collective-bargaining agreements are unquestionably protected by the nonstatutory labor exemption. ${ }^{113}$ Agreements between the union and the job owner to exclude nonunion contractors, by contrast, can be thouglit of as exclusive-dealing arrangements. In this sense, section 3 is simply the corollary of the prohibition against group boycotts. ${ }^{114}$ Direct agreements between the umion and job owners, as opposed to those between the umion and union contractors, seem to constitute exclusive-dealing arrangements.

\section{Cartel Facilitation}

The umion's boycotts of nonunion contractors might serve a purpose apart from excluding those contractors from the market: they could facilitate a cartel ainong union contractors. As discussed above, the union might be able to police a cartel effectively, and thereby substantially mcrease the profits of union contractors. ${ }^{115}$ This is the "cartel ringmaster" theory that gained prominence more than fifty years ago with the Supreme Court's decision in Interstate Circuit, Inc. v. United States. ${ }^{116}$

There are two versions of the cartel-facilitation theory, both expressed in Interstate Circuit. The broader view would nrake all "conscious paralletisin" illegal, whether or not competitors actually agreed to

112. See Tampa Elec. Co. v. Nashville Coal Co., 365 U.S. 320, 333 (1961) (exclusive-dealing arrangements covering $1 \%$ of market "quite insubstantial" and insufficient to show antitrust violation); Standard Oil, 337 U.S. at 295,314 (exclusive-dealing arrangements covering $6.7 \%$ of market violated section 3); see also 3 AREEDA \& TURNER, supra note 55, para. 731e (exclusivedealing arrangement by monopolist presumptively illegal).

113. See infra text accompanying notes 174-83.

114. Unlike the traditional exclusive-dealing case, the job owner is not agreeing to deal with the union directly at all, but with umion contractors. The union nonetheless ought to be liable in this instance because it sponsored the agreement. Parties can violate the antitrust laws by restraining trade im a market even if they are not themselves in that market. Altemose Constr. Co. v. Atlantic, Cape May, \& Parts of Burlington, Ocean \& Cumberland Counties Bldg. Trades Council, $493 \mathrm{~F}$. Supp. 1181, 1190 (D.N.J. 1980) (unions); see also Costello Publishing Co. v. Rotelle, 670 F.2d 1035, 1046-48 (D.C. Cir. 1981) (church's effort to encourage book sellers not to sell plaintiff's book may violate antitrust laws); Richter Concrete Corp. v. Hilltop Basic Resources, Inc., 547 F. Supp. 893, 899 (S.D. Ohio 1981) (company can conspire to monopolize a market in which it does not compete), aff'd 691 F.2d 818 (6th Cir. 1982); Cape Cod Food Prods., Inc. v. National Cranberry Ass'n, 119 F. Supp. 900, 909 (D. Mass. 1954) (defendant need not be member of a market in order to conspire to monopolize it).

115. See supra notes $65-70$ and accompanying text.

116. 306 U.S. 208 (1939); see also supra text accompanying note 69 (discussing the "cartel ringmaster" theory). 
set prices. Interstate Circuit took this view in an alternative holding: "we think that in the circuunstances of this case such agreement for the imposition of the restrictions upon subsequent-run exhibitors was not a prerequisite to an unlawful conspiracy." "117 In the Court's view, an identical pattern of actions by ohgopolists itself violated the antitrnst laws. ${ }^{18}$ While the conscious-parallelism theory has received some support from a surprising source-Judge Richard Posner ${ }^{119}$-it has been widely disparaged by both courts ${ }^{120}$ and commentators. ${ }^{121}$ Conscious parallelism would lead to liability without fault in concentrated imdustries in which mterdependent pricing is the only rational busmess strategy or in which little variation im prices is possible. This result seems unwarranted.

Interstate Circuit also stands for a narrower proposition; namely, that a court properly may draw inferences of collusion from parallel pricing and otlier, similar behavior. ${ }^{122}$ Courts liave been far more sympathetic to such inferences, ${ }^{123}$ especially when there are so-called "plus factors,"124 thian they liave been to the conscious-parallelism theory.

The market structure and the motivations of unions and union contractors are quite similar to tliose at issue in Interstate Circuit. In both cases, there is a "rimless wheel": one central agent, the union, can coor-

117. Interstate Circuit, 306 U.S. at 226.

118. Id. at 226-27.

119. Richard A. Posner, Oligopoly and the Antitrust Laws: A Suggested Approach, 21 STAN. L. REv. 1562, 1575-87 (1969) (suggesting that noncompetitive pricing by oligopolists necessarily violates section 1).

120. See, eg., Theatre Enters. v. Paramount Film Distrib. Corp., 346 U.S. 537, 541 (1954) ("[T]his Court has never held that proof of parallel business behavior ... itself constitutes a Sherman Act offense. ... ‘[C]onscious parallelisin' has not yet read conspiracy out of the Sherman Act entirely."); Clamp-All Corp. v. Cast Iron Soil Pipe Inst., 851 F.2d 478, 484 (1st Cir. 1988) (individual interdependent pricing decisions do not violate Sherman Act), cert. denied, 488 U.S. 1007 (1989); Wilcox v. First Interstate Bank, 815 F.2d 522, 526 (9th Cir. 1987) (parallel prime lending rate not a violation of Sherman Act).

121. E.g., 6 AREEDA, supra note 70 ๆ 1426'; Fox \& SullivaN, supra note 70, at 457.

122. Interstate Circuit, 306 U.S. at 221-23.

123. See, e.g., Theatre Enters, 346 U.S. at 540 ([P]arallel "behavior is admissible circumstantial evidence from which the fact finder may infer agrecinent."); In re Coordinated Pretrial Proceedings in Petroleum Prods. Antitrust Litig., 906 F.2d 432, 462-63 (9th Cir. 1990) (reversing grant of summary judgment because parallel behavior in coinbination with other evidence presented issue of fact as to existence of cartel), cert. denied sub nom. Chevron Corp. v. Arizona, 111 S. Ct. 2274 (1991); City of Long Beach v. Standard Oil Co., 872 F.2d 1401, 1407 (9th Cir.) (parallelisin can support jury verdict finding cartel), modified, 886 F.2d 246 (1989), cert. denied, 493 U.S. 1076 (1990); Barry v. Blue Cross, 805 F.2d 866, 869 (9th Cir. 1986) (parallehisin can imply agreement if there is economic interdependence among actors); Park v. El Paso Bd. of Realtors, 764 F.2d 1053, 1061 (5th Cir. 1985) (parallelisin can support jury verdict finding cartel), cert. denied, 474 U.S. 1102 (1986).

124. See Phillip AREeda \& Herbert Hovenkamp, ANTtTrust LAW: AN ANALysis of ANTtTrust Principles ANd Their ApPlication đ 1434', at 970 (Supp. 1991). The term refers to other evidence of agrecment besides parallel behavior. Such extra evidence is inportant because competition as well as collusion can drive prices to uniformity. See Fox \& Sull1VaN, supra note 70, at 457 . 
dinate the activities of a number of downstream firms, the umion contractors. Antitrust plaintiffs are more likely to prevail if they can prove that a union orchestrates a boycott by union contractors of job owners who do not comply with their demands. What is generally missing, though, is evidence of even vertical agreenents setting prices in the contracting market. The cartelization claim is similar to the group-boycott claim, but characterizing union conduct as a horizontal cartel, if successful, invokes the per se rule. ${ }^{125}$ However, evidence of urion threats to sue and of lawsuits against job owners does not seem to go very far towards proving a horizontal price agreement anong contractors. While the cartel theory is viable from an economic standpoint, and is a powerful antitrust weapon, it seeins destined to fail in the absence of more direct evidence of collusion.

\section{Anticompetitive Litigation}

Some courts and commentators have suggested that litigation, threats of litigation, or petitioning before administrative agencies can constitute independent antitrust violations if motivated by anticoinpetitive interests. ${ }^{126}$ However, no antitrust statute prohibits anticompetitive litigation itself, at least absent collusion. Instead, these authorities are better read to suggest that bad faitl litigation or petitioning can be anticompetitive conduct sufficient to establisli one eleinent of a inonopolization claim. ${ }^{127}$ There is a substantially broader consensus for this proposition. ${ }^{128}$ Litigation can also be a meehanism for facilitating a car-

125. While the Court is cutting back the scope of the per se rule in a variety of contexts, horizontal price-fixing remains solidly withm its ambit. See FTC v. Superior Court Trial Lawyers Ass'n, 493 U.S. 411, 434-36 (1990); FTC v. Indiana Fed'n of Dentists, 476 U.S. 447, 458-59 (1986); Jorde \& Lemley, supra note 108, at 302-05.

126. See CVD, Inc. v. Raytheon Co., 769 F.2d 842, 851 (1st Cir. 1985) ("II]t seems clear that the assertion of a trade secret claim in bad faith, in an atteinpt to monopolize, can be a violation of the antitrust laws."), cert. denied, 475 U.S. 1016 (1986); Omni Resource Dev. Corp. v. Conoco, Inc., 739 F.2d 1412, 1413 (9th Cir. 1984) (antitrust claim can be based on an opponent's litigation conduct if that litigation was a sham); BoRK, supra note 49, at 354 ("Certainly, in a proper case, a proved intent . . . by the hitigation of baseless claims, to bar [coinpetitors] from a market or to delay their entry should suffice for violation of the Sherman Act." (einphasis added)).

127. In the Ninth Circuit, of course, as noted supra notes $81-85$ and accompanying text, it is possible to infer intent from conduct and dangerous probability of success froin intent and conduct. Thus, it may be accurate to state that anticompetitive litigation in some cases will suffice to prove an antitrust violation. Nonetheless, to claim that it is itself a violation seems highly misleading.

In any event, inuch hitigation is protected by Noerr-Pennington inmunity, and hence could not constitute an antitrust violation, even in the Ninth Circuit. See infra text accoinpanying notes 193201 (discussion of the Noerr-Pennington doctrine).

128. See, e.g., New Motor Vehicle Bd. v. Orrin W. Fox Co., 439 U.S. 96,110 n.15 (1978) (sham protests intended solely to delay the establishinent of competing dealerships may be subject to the antitrust laws); Central Telecoininuirications, Inc. v. TCI Cablevision, Inc., 800 F.2d 711, 722 \& n.11 (8th Cir. 1986) (lobbying efforts were "heavy-handed attempts to directly interfere with the business relationships of a competitor"), cert. denied, 480 U.S. 910 (1987); Neumann v. Reinforced Earth Co., 786 F.2d 424, 426 (D.C. Cir.) ("It is not enough to be found to have attempted to 
tel or group boycott. Here again, however, the hitigation is merely one element of a larger claim that the combination itself is illegal.

Vexatious litigation can impose tremendous costs on competitors that ought to be cognizable under the antitrust laws in certain circumstances. ${ }^{129}$ Union hability for patterns of higation like those described here will depend on the application of the Noerr-Pennington doctrine ${ }^{130}$ and the labor exemption, ${ }^{131}$ which place significant limits on union hability under a nionopolization theory. A distinction should be drawn between a union seeking niarket power by expanding union menbership, which should be protected activity, ${ }^{132}$ and one seeking power by excluding competitors from product markets, whicls should be an antitrust violation.

\section{Conclusions}

The union activities discussed im this Comment are most logically characterized in antitrust terms as eitlier an atteinpt to monopolize or a group boycott. Antitrust litigation directed against the unions, if cast in this light, has a significant chance of succeeding on tle nierits. ${ }^{133}$ Such

monopolize that the party's sole intent in bringing an action is to exclude a rival from the market."), cert. denied, 479 U.S. 851 (1986); Rickards v. Canine Eye Registration Found., 783 F.2d 1329, 1334 (9th $\mathrm{Cir}$.) ("Our cases require ... that [a] sham lawsuit be accompanied by additional evidence of anticompetitive activity before [Noerr-Pennington] immuuity will be called off."), cert. denied, 479 U.S. 851 (1986); Conceptual Eng'g Assocs. v. Aelectronic Bonding, Inc., 714 F. Supp. 1262, 1266 (D.R.I. 1989) (listing the criteria to establish a violation of Sherman Act as bad faith litigation plus specific intent to inonopolize market plus dangerous probability of success plus antitrust damages attributable to defendant's actions); Brownlec v. Applied Biosystems, Iuc., 1989-1 Trade Cas. (CCH) 1] 68,425, at 60,338 (N.D. Cal. 1989) ("[T]hreats of hitigation, used as a bludgeon in an attempt to obtain monopoly . . . indicate grave abuse on the part of a defendant."); $c f$. City of Lafayette v. Louisiana Power \& Light Co., 435 U.S. 389, 405 (1978) (notimg that litigation can lave anticompetitive consequences, and apparently assuming tliat it can constitute an antitrust violation), overruled on other grounds by Hallie v. Eau Claire, 471 U.S. 34 (1985).

129. See, e.g., Lousiana Power, 435 U.S. at 405 (noting in dictum that vexatious litigation can impose "enorinous unnecessary costs"); Premier Elec. Constr. Co. v. National Elec. Contractors Assoc., 814 F.2d 358, 376 (7th Cir. 1987) (litigation can be used as a device for iniposing costs on competitors).

130. See infra Part V (applying the Noerr-Pennington doctrine to the union activity described here).

131. See infra Part IV (discussion of labor exentption as applied to this union activity).

132. See infra Section IV.B (discussion of the nonstatutory exeniption).

133. The antitrust injury doctrine limits the standing of private plaintiffs under the antitrust laws. Standing, however, should present no obstacle to claims by nonunion contractors or job owners in the circuunstances described here. In Associated General Contractors, Inc. v. California State Council of Carpenters, 459 U.S. 519 (1983), the Court denied standing to a union challenging a conibination of nonunion contractors to exclude union contractors from jobs (the opposite situation fron that described in this Cominent). The Court noted explicitly that "a contracting or subcontracting firn that refused to yield to the defendants' coercive practices and therefore suffered whatever sanction that coercion iniposed . . could maintain an action against the defendants." Id. at 540 n.44. Private plaintiffs should therefore be able to maintain an antitrust action on these facts. The antitrust injury doctrine does not, of course, bar suits by governinent agencies to enforce the antitrnst laws. 
litigation will most likely be resolved under the rule of reason, which applies both to monopolization and, we think, to group-boycott claims. ${ }^{134}$ Many plaintiffs have seen the rule of reason as a cause for despair, associating the shift towards the rule of reason with the Suprene Court's recent skepticism towards antitrust claims in general. The Court made it clear in National Society of Professional Engineers v. United States, ${ }^{135}$ however, that the rule of reason does not open the door to every asserted justification for a defendant's actions. Instead, "the inquiry is confined to a consideration of impact on competitive conditions." 136 In other words, once a union's actions are determined to fall outside the labor exeinption, it must defend thein on grounds relating to competition; thus, a defense on the grounds that such actions further labor policy or that anticompetitive restrictions are otlerwise desirable in a particular imstance will be unsuceessful. ${ }^{137}$

Unions will have an uphill fight to meet this burden. The goal of the boycott program is to exclude nonunion competitors from the market, to raise wages, and, allegedly, to help the environment. The last arguinent cannot justify a union's conduct under the rule of reason because it is irrelevant to competition, ${ }^{138}$ and the first two goals are theinselves anticompetitive. There does not seem to be any efficiency justification for threatening or sunig downstream firms in an attempt to exclude competitors. Furthermore, there is good reason to be concerned about the competitive consequences of sucl actions. ${ }^{139}$ This seems, then, a paradigm case in which the rule of reason will not protect an antitrust defendant.

134. See supra notes 108-11 and accompanying text. A cartel theory, if provable, would bring the case within the per se rule. See supra Section III.B.4 (discussing cartel-facilitation theory).

135. 435 U.S. 679 (1978).

136. Id. at 690 .

137. At least one court has suggested that a holding that the labor exemption does not apply ought to suffice to find an antitrust violation without a court ever applying the rule of reason. In Consolidated Express, Inc. v. New York Shipping Ass'n, 602 F.2d 494 (3d Cir. 1979), vacated on other grounds, 448 U.S. 902 (1980), the court rejected the rule of reason in such a case:

The justification offered for application of the rule of reason is the need to recognize, in the antitrust context, labor's legitimate interest in the collective bargaining process. That interest, however, is precisely the same one that must be taken into account in determining the scope of the nonstatutory labor exemption. A holding that the exemption does not apply embodies a judgment that considerations of labor policy are outweighed by the anticompetitive dangers posed by the challenged restraint. . . . The appellees have suggested no reason why a sccond such inquiry is necessary or appropriate.

Id. at 523-24. We think the court's reasoning is salutary, but its conclusion that the rule of reason should not apply is unwarranted. There is still a need to evaluate the coinpetitive effects of the union's practice on its antitrust merits. That evaluation-and ouly that evaluation-should be conducted under the rule-of-reason inquiry.

138. See supra text accompanying notes 135-36. As discussed above, effects on the environment would, however, be relevant to the initial determination of the union's intent in bringing a lawsuit.

139. See supra Section III.A. 


\section{IV \\ THE LABOR EXEMPTION}

There are two important obstacles to union liability for a pattern of anticompetitive litigation: (1) the labor exemption, discussed in this Part; and (2) Noerr-Pennington immunity, discussed in Part V.

The labor exemption to the antitrust laws protects certain union activities froin antitrust scrutiny. For example, under the labor exemption, unions may legitimately sign wage agreements witl employers and organize workers into labor unions. There is both a statutory and a nonstatutory labor exemption to the antitrust laws. The statutory exeinption follows directly from the langnage of the Norris-LaGuardia Act, ${ }^{140}$ while the nonstatutory exemption reflects a judicial policy decision to allow certain combimations between unions and nonlabor groups, sucl as collective bargaining agreements, in order to allow umions to function effectively. ${ }^{141}$ The scope of the labor exemption is unclear, and it lias been applied inconsistently by the courts. ${ }^{142}$ We believe tliat the statutory exemption is best understood as encompassing only unilateral union activity tliat is in the union's legitimate self-mterest, and that the nonstatutory exemption is limited to certain activities related to collective bargaining agreements.

\section{A. The Statutory Exemption}

The National Labor Relations Act ${ }^{143}$ was intended to enhance workers' earnings througl collective action. The preainble to the Act suggests that Congress was reacting to economic problems that were "depressing wage rates and the purcliasing power of wage earners in imdustry." 144 The intent of the labor laws was "to transfer wealth to labor from employers and, to a lesser extent, consumers." 145 Thus, unions are in essence statutorily sanctioned nonopolies that seek to elim-

140. 29 U.S.C. $\S \S 101-115$ (1988) (reaffirming protections of Clayton Act, 15 U.S.C. $\S 52$ (1988)).

141. Areeda and Turner have argued that the use of the terminology "statutory" and "nonstatutory" is unfortunate because the nonstatutory exemptions relate to activities contemplated by the statutory provisions. See 1 AREEDA \& TURNER, supra note 55 , If 229b, at 192 . The nonstatutory exeinption cannot be implied from a literal reading of the statute, however, and thus appears to represent a judicial more than a congressional judgment as to the necessity for such an exemption. See infra text accompanying notes 167-69.

142. For example, the Ninth Circuit heard a case on facts similar to those considered here and found plaintiffs' antitrust claim to be barred by Noerr-Pennington iminunity. Franchise Realty Interstate Corp. v. San Francisco Local Joint Executive Bd. of Culinary Workers, 542 F.2d 1076 (9th Cir. 1976), cert denied, 430 U.S. 940 (1977). The court did not address the labor exemption. The dissent argued that the complaint stated an antitrust claim. Id. at 1086 (Browning, C.J., dissenting).

143. 29 U.S.C. §§ 151-169 (1988).

144. Id. § 151.

145. See Campbell, supra note 50, at 994 n.13. 
inate competition over wages and working conditions. ${ }^{146}$ As a result, the goals of the labor laws are in conflict with the fundamental premise of antitrust law-that competition is inherently beneficial. ${ }^{147}$

This tension between anticompetitive umion activity and the goals of antitrust was initially resolved in favor of competition. In the years immediately following the passage of the Sherman Act, the Court enjomed strikes as unlawful restramts of trade when the umion's conduct or objectives were found to be "socially or econoinically harmful."148

In response to this conflict between labor pohicy and the goals of antitrust, Congress enacted statutes that exempted certain umion activities from antitrust scrutiny. Section 6 of the Clayton Act states that human labor "is not a commodity or article of commerce" and immunizes labor organization activities designed to carry out the "legitimate" purposes of labor umions from claims under the antitrust laws. ${ }^{149}$ Section 20 of the Clayton Act prohibits injunctions against legitimate employee activities in the course of disputes over "terms or conditions of einployments."150 These protections were reaffirmed by the Norris-LaGuardia Act, which shields legitinate urnon activities conducted unilaterally in pursuit of union goals. ${ }^{151}$

As a general inatter, exemptions froin the antitrust laws are to be construed narrowly. ${ }^{152}$ Umion conduct is exempt under the statutory

146. See id. at 1005 (identifying monopolization as the goal of unionized labor).

147. See H.A. Artists \& Assocs. v. Actors' Equity Ass'n, 451 U.S. 704, 713 (1981) ("[T]here is an inherent tension between national antitrust pohicy, which seeks to maximize competition, and national labor policy, which encourages cooperation among workers to improve the conditions of employment."); see also National Soc'y of Professional Eng'rs v. United States, 435 U.S. 679, 695 (1978) (the Sherman Act is based on "[t]he assumption that competition is the best niethod of allocating resources in a free market").

148. See Duplex Printing Press Co. v. Deering, 254 U.S. 443, 485 (1921) (Brandeis, J., dissenting) (discussing judicial determination of the harm caused by labor unions).

149. 15 U.S.C. $\S 17$ (1988). Seetion 6 reads in full:

The labor of a human being is not a coinunodity or article of comunerce. Nothing contained in the antitrust laws shall be construed to forbid the existence and operation of labor, agricultural, or horticultural organizations, instituted for the purposes of mutual help, and not having capital stock or conducted for profit, or to forbid or restrain individual meinbers of such organizations from lawfully carrying out the legitintate objects thereof; nor shall such organizations, or the members thereof, be held or construed to be illegal Id. combinations or conspiracies in restraint of trade, under the antitrust laws.

150. 29 U.S.C. $\$ 52$ (1988).

151. 29 U.S.C. $\S \S 101-115$ (1988). The Norris-LaGuardia Act was not explicitly phrased as an exemption from the antitrust laws; however, it has been interpreted broadly as a statement of congressional policy that antitrust is limited in its use as a vehicle for interfering in a labor dispute. See Milk Wagon Drivers' Union, Local No. 753 v. Lake Valley Farm Prods., Inc., 311 U.S. 91, 10203 (1940).

152. Uirion Labor Life Ins. Co. v. Pireno, 458 U.S. 119, 126 (1982); see also John S. Wiley Jr., $A$ Capture Theory of Antitrust Federalism, 99 HARv. L. REv. 713, 713 n.1 (1986) (listing cases reflecting the Court's unwillingness to create or imply antitrust exemptions and its narrow interpretation of those exemptions). 
exemption "[s]o long as a union acts in its self-interest and does not combine with non-labor groups." 153 This language has been interpreted by the Supreme Court as requiring that a union act in its legitimate selfinterest. $^{154}$

While the language of the statutory exeinption appears unequivocal, some courts have questioned whether a union must satisfy both prongs of the test in order to fall within the exeinption. ${ }^{155}$ The Supreme Court has suggested that union activity should be exeinpted froin the antitrust laws only if it meets both tests-that is, only if the union activity is conducted for a legitimate purpose and is unilateral. In H.A. Artists \& Associates, Inc. v. Actors' Equity Association ${ }^{156}$ the Court considered the second prong of the test-combination with nonlabor groups-even though it found that the union acted in its legitimate self-interest. Such scrutiny would have been unnecessary were the union only required to satisfy one prong of the test. Moreover, the Court held that "[ $t]$ he statutory exemption does not apply when a union coinbmes with a "non-labor group." "157 $H$.A. Artists thus supports the proposition that a union inust act unilaterally and in its legitimate self-interest in order for the statutory labor exemption to apply. ${ }^{158}$

At least one lower court, however, has reached the conclusion that either unilateral union action or a legitimate purpose is sufficient to invoke the statutory exemption. In USS-POSCO Industries v. Contra Costa Building \& Construction Trades Council the court found that the statutory exemption apphes to unilateral action, regardless of whether the uunon's purpose was legitimate. ${ }^{159}$ Similarly, concerted action was protected so long as the purpose was legitimate. The court thus con-

153. United States v. Hutcheson, 312 U.S. 219, 232 (1941) (emphasis added). The Court also stated that "the licit and the illicit under $\$ 20$ [of the Clayton Act] are not to be distinguished by any judgment regarding the wisdom or unwisdom, the rightness or wrongness, the selfishness or unselfishness of the end of which the particular nnion activities are the nieans." Id. As later courts have made clear, however, the union's nieans-as opposed to its ends-must be legitimate. See, e.g., H.A. Artists \& Assocs. v. Actor's Eqnity Ass'n, 451 U.S. 704, 722 (1981) (finding that fees levied by defendant union were not exenipt fron antitrust regulation even though they arguably provided a means to legitimate union ends).

154. See, e.g., United Mine Workers v. Pennington, 381 U.S. 657, 663 (1965) (suggesting that a union seeking to protect wages by requiring employers to charge a particular price for their product would not be exempt from antitrust condemnation).

155. Compare USS-POSCO Indus. v. Contra Costa Bldg. \& Constr. Trades Council, 1990-2 Trade Cas. (CCH) $\uparrow 69,095$, at 64,033 (N.D. Cal. 1990) (union nust satisfy only one prong) with Imperial Constr. Managennent Corp. v. Laborers Int'1 Union, Local 96, 729 F. Supp. 1199, 1209 (N.D. Ill. 1990) (union ninst satisfy both prongs) and A \& D Snpermarkets, Inc. v. United Food \& Commercial Workers, Local Union 880, 732 F. Supp. 770, 773 (N.D. Ohio 1989) (same).

156. 451 U.S. 704 (1981).

157. Id. at 715 .

158. See also $A \&$ D Supermarkets, Inc, 732 F. Supp. at 773 (noting that both of these elenients must be alleged to withstand a Rule 12(b)(6) motion).

159. 1990-2 Trade Cas. (CCH) \ 69,095 at 64,033-34 (N.D. Cal. 1990). 
cluded that a single union acting alone cannot conduct activities that fall outside the exeinption, while a combination is illegal only if coupled with an illegitimate purpose. "To retain its statutory exemption, a umion combining with a non-labor group must also act in its self-interest . . . "160 USS-POSCO apparently has misinterpreted the language of the statutory exemption. This confusion on the part of the court resulted froin a conflation of the statutory and nonstatutory exemptions. Under the nonstatutory exemption, unions inay combine with other groups so long as they have a legitimate, but more narrowly circuniscribed, purpose. ${ }^{161}$

Assuming then that union activity must be both legitimate and unilateral to fall under the statutory exemption, there is soine question under current law as to whether the umion activity considered in this Comment would satisfy that standard. In Imperial Construction Management Corp. v. Laborers International Union Local 96 the court found that in order to avoid the application of the statutory exemption on a theory of combination with a nonlabor group, the combination must directly benefit the nonlabor entity. ${ }^{162}$ The court held that when the only apparent benefit to the union contractors would be the elimination of coinpetition based on labor costs, the statutory exemption was still applicable. ${ }^{163}$ The court's reasoning appears to have been that the union conduct did not really involve a "coinbination" with a nonlabor group, because a coinbimation implies a benefit to that group. ${ }^{164}$

In United Mine Workers v. Pennington, ${ }^{165}$ however, the Supreme Court held that, while a union can make wage agreements with a multiemployer bargaining unit, it forfeits the statutory labor exeniption when it agrees with a group of employers to impose a certain wage scale on other bargaining umits. ${ }^{166}$ When a union tacitly agrees with umion contractors and merit-shop contractors-who are coerced into signing project agreements-to oppose the permit applications of other contraetors who do not comply, this standard may be inet. This union strategy raises the costs of using other contractors. The union is thus attempting to set a price in the product market by increasing the costs of using merit-shop contractors, thereby reducing price competition between union and nonunion contractors. This is precisely the sort of conduct that Pennington condenins.

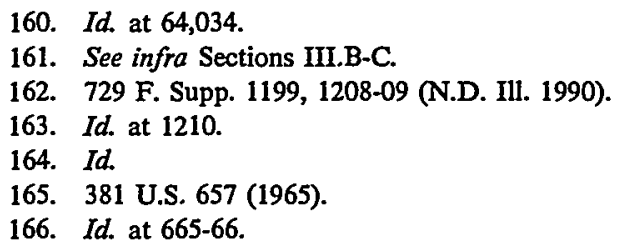




\section{B. The Nonstatutory Exemption}

The statutory language of the labor exemption subjects any agreement between a union and its employer to the scrutiny of the antitrust laws. The Supreme Court, however, has recognized that unions must be able to make collective bargaining agrecments if they are to achieve their goals. To this end, the Court has created a nonstatutory exemption ${ }^{167}$ in addition to the statutory exemption previously discussed. ${ }^{168}$ Labor policy favors "the association of employees to eliminate competition over wages and working conditions." 169 In order to fall within the nonstatutory exemption, the umion must have a legitimate goal and pursue that goal through the channels sanctioned by labor policy. A collective bargaining agreement and conduct directed towards securing such an agreement is exempt from antitrust scrutiny so long as such conduct is in concert with the general goals of national labor policy.

In Connell Construction Co. v. Plumbers \& Steamfitters Local Union No. 100 the Court held that an agreement between a general contractor and a union that the contractor would use exclusively union contractors did not fall within the nonstatutory exemption. ${ }^{170}$ The agreenient was part of a multieniployer plan in which the union agreed that if it granted a more favorable contract to any employer, it would extend the same terms to all signatories. The union picketed only those general contractors who resisted the plan. The Court held that "[t]he agreements with Connell and other general contractors indiscriminately excluded nonunion subcontractors from a portion of the market, even if their competitive advantages were not derived froni substandard wages and working conditions but rather from more efficient operating inethods."171 The Court observed that the "complete control" exerted by the union over the subcontracts of those general contractors that entered the agreements could have "significant adverse effects on the market and on consunierseffects unrelated to the union's legitimate goals of organizmg workers and standardizing working conditions." 172

Although the Court ultimately concluded that the union's goal was legal, it did not end its mquiry there:

[T]he methods the union chose are not immune from antitrust sanctions simply because the goal is legal. . . This kind of direct restraint on the business market has substantial anticompetitive effects, both actual and potential, that would not follow naturally from the elimination of compe-

167. The nonstatutory exemption was first explicitly recognized in Connell Construction Co. v. Plumbers \& Steamfitters Local Union No. 100, 421 U.S. 616, 625 (1975).

168. The statutory exemption was discussed supra text accompanying notes 153-54.

169. Connell, 421 U.S. at 622.

170. Id. at 625-26.

171. Id. at 623 .

172. Id. at 624 . 
tition over wages and working conditions. It contravenes antitrust policies to a degree not justified by congressional labor policy, and therefore cannot claim a nonstatutory exemption from the antitrust laws. ${ }^{173}$

Connell concludes that a union cannot approach a contractor with whom it has no extant relationship and pressure it into signing an agreement to use exclusively union contractors. The bar applies even if the goal of such pressure is the signing of collective-bargaining agreements. ${ }^{174}$ Therefore, only collective-bargaining agreements themselves and legitimate activities anned directly at obtaining such agreements between the parties to the action are nonstatutorily exempt. ${ }^{175}$

The Nimth Circuit has interpreted Connell to mean that tlie "nonstatutory exemption prevents the antitrust laws from being used to frustrate the primary and legitimate goal of the federal labor law, whicl is to permit employees to organize and act to improve wages and working conditions." "176 In Richards v. Neilsen Freight Lines the court refused to interpret Connell as limitimg the scope of tlie nonstatutory exemption to collective bargaining agreements. ${ }^{177}$ The case imvolved a umion's agreement witl its employers forbidding the employers from dealing with the plaimtiff firm. The agreement was potentially illegal under the labor law's prohibition of secondary boycotts or liot-cargo agreements. ${ }^{178}$ The court found that a violation of the labor laws did not mandate antitrust liability because tlie labor laws provided an adequate remedy. ${ }^{179}$ Richards distin. guislied Connell on tle ground tliat in Connell the industry-wide boycott was "brought to bear on employers witlı wliom the umion had no collec-

173. Id. at 625 (emphasis added).

174. Minimum wage provisions would be more narrowly tailored to meeting concerns about working conditions and wages than threats of environmental litigation. See id. at 624-25 (condemning restraint as too broad because not narrowly tailored to protect a legitimate union interest). The nonstatutory exemption is designed to protect necessary union activity. The union must use the least restrictive means of achieving its legitimate goals if its conduct is to be exempt. For example, insofar as the northern California unions are concerned about environmental problems, they should target firms whose projects are demonstrably probleniatic fron an environmental perspective and not on the basis of whether umion labor is involved. This apparently has not been urion policy. See supra text accompanying notes 22-23.

175. See Connell, 421 U.S. at 622 (the nonstatutory exemption bars unions from imposing direct restraints on competition on those who employ union members).

176. Richards v. Neilson Freight Lines, 810 F.2d 898, 905 (9th Cir. 1987).

177. Id. The Ninth Circuit reasoned that the Connell Court examined the anticonipetitive effects of the challenged contract, which was not a collective bargaining agreement. Such an examination would not have been required had the test excluded all agreenients other than valid collective bargaining agreements. Id. The Connell Court, however, concluded that the agreenient was illegal precisely because it was not a collective bargaiming agreement and thus did not conport with national labor policy. Connell, 421 U.S. at 625-26.

178. See AREedA \& HovenKAMP, supra note 124, ๆ 229.2a, at 240.

179. Richards, $810 \mathrm{~F} .2 \mathrm{~d}$ at 906 . The adequacy of the renedy under the labor laws is suspect because the labor laws are not designed to examine the anticompetitive effects of the challenged conduct. See Connell, 421 U.S. at 626-34 (reviewing the legislative history of NLRA $\$ 8$ and concluding that labor law remedies in the Act were not intended to be exclusive). 
tive-bargaining relation, and it was directed to employees in which the union had no representational interest." 180 Even if Richards is consistent with Connell, it is limited to protecting only union boycotts of einployers with whon the uinon has an extant collective bargaining relationship. ${ }^{181}$

Still, other courts have limited the nonstatutory exeinption to valid collective-bargaining agreements. In $C \& W$ Construction Co. v. Brotherhood of Carpenters \& Joiners, Local $745^{182}$ the court found that " " $\left.t\right]$ he nonstatutory exenıption . . . inay be invoked in cases involving valid collective bargaining agreenients between unions and einployers on wages or working conditions." "183 Since there was no valid collective-bargaining agreenient, the court concluded that the nonstatutory exeinption did not apply.

In Allen Bradley Co. v. Local Union No. 3, International Brotherhood of Electrical Workers ${ }^{184}$ the Suprenie Court found conduct similar to that described in this Comment ${ }^{185}$ to be outside the nonstatutory exenuption. An electrical workers' union entered into a variety of closed-shop agreeinents with inanufacturers and contractors that inured to the financial profit of all parties. The group led boycotts of all the noncoinphant parties, innltiplying the jobs available for the union and restricting coinpetition froin the other groups. The Court held that labor unions cannot conibine with einployers to restrain coinpetition in the eniployer's inarket. ${ }^{186}$ The labor exeniptions do not extend to conduct designed to enable unions, together with nonlabor groups, to control the inarketing of goods and services, even though the unions are furthering the interests of their inenibers as wage earners: "A business inonopoly is no less such because a union participates . . . ."187

\section{Applications}

In evaluating the uinon hitigation strategy described in this Comment, it is important to distinguish between two inethods of acquiring inonopoly power. The first inethod, by which the union atteinpts to recruit nonunion workers-its competitors-or "recruit" nonunion con-

180. Richards, 810 F.2d at 905.

181. This limitation on Richards received inferential support in In re Detroit Auto Dealers Ass'n, 955 F.2d 457, 464 (6th Cir. 1992). That case found that the fact that some auto dealers liad bargaining relationships with unions requiring them to reduce slowroom loours did not immunize an agreement among all auto dealers reducing tlose lours.

182. 687 F. Supp. 1453 (D. Haw. 1988).

183. Id. at 1464 (quoting Sun-Land Nurseries, Inc. v. Southern Cal. Dist. Council of Laborers, 793 F.2d 1110, 1115 (9th Cir. 1986) (en banc), cert. denied, 479 U.S. 1090 (1987)).

184. 325 U.S. 797 (1945).

185. See supra Part II.

186. Allen Bradley, 325 U.S. at 808 . The plaintiffs sued under a monopolization theory. Id. at 798,810 .

187. Id. at 811 . 
tractors by negotiating collective bargaining agreeinents with thein, is squarely within the conduct envisioned by the labor laws and should receive protection under the labor exeinption. The second inethod, by which the union atteinpts to acquire market power by driving nonunion contractors out of the market rather than signing collective bargaining agreeinents with them, should not be exempt from antitrust scrutiny.

Umion conduct is not exeinpt under the statutory exeinption if it is either a combination with a noulabor group or is not im the umon's legitimate self-interest. To the extent that a union acts to facilitate a cartel of umion contractors, or agrees with those contractors that im return for signing project agreements it will contimue its pohcy of instituting hitigation against merit-shop contractors, it would be a party to a conspiracy with noulabor groups under Pennington. Also, coerced agreeinents between a job owner or a general contractor and the umion that only union contractors will be used could constitute combinations with nonlabor groups that are not statutorily exempt. These combinations might, however, fall within the nonstatutory exemption discussed above. ${ }^{188}$

The union may also fail the second prong of the test. In order to show a legitimate umion purpose, a umion must have both a legitimate goal and a legitinate means of attaining that goal. ${ }^{189}$ The elimination of competition over wages and working conditions is a legitimate union goal, but the same cannot necessarily be said of the elimination of meritshop contractors. Moreover, the actual or threatened filing of harassing lawsuits would not constitute legitimate union conduct. ${ }^{190}$ Thus, such a litigation strategy does not fall within the statutory labor exeinption.

The umion litigation strategy also fails to meet the test for application of the nonstatutory exeinption. The union's conduct is similar to that in Connell and Allen Bradley, which the Court found to fall outside the nonstatutory exeinption. The unions are pressuring job owners to sign project agreeinents that guarantee that all labor used in tlie construction process will be union labor and that all contractors will be union firms. There is no evidence that the nonunion contracting firms are the direct targets of union organizinig activity. Instead, the unions appear to be working with either the job owners or the union contractors to restrict conpetition in the contractor niarket. ${ }^{191}$ The goal of the pro-

188. See supra Section IV.B.

189. See Connell Constr. Co. v. Plumbers \& Steamfitters Local Union No. 100, 421 U.S. 616, 625 (1975).

190. See infra notes 211-34 and accompanying text.

191. The Richards court found that the umion conduct did not eliminate competition. Richards v. Neilson Freight Lines, 810 F.2d 898, 906 (9th Cir. 1987). By agreemg to use union labor, the excluded firm still could exploit all the competitive advantages stemming from factors other than wages and working conditions. Id. at 906 . This rationale is somewhat naive because union and nonunion firms can have union-specific characteristics other than wages and working conditions that impact their efficiency (such as employee morale and transaction costs involved in labor 
gram is to drive merit shops out of the market. This goal cannot be characterized as legitimate under Connell. Moreover, the conduct is not in furtherance of a collective-bargaining agreement with merit-shop contractors excluded from the inarket. Therefore, the conduct does not fall withim the nonstatutory exemption.

\section{$\mathrm{V}$ \\ NOERR-PENNINGTON IMMUNITY}

\section{A. The Noerr-Pennington Doctrine}

Even if the union's conduct does not fall within the labor exemption, the filing of regulatory actions and lawsuits may be protected under a different antitrust exception. The Noerr-Pennington doctrine protects some petitioning activity directed at government agencies. This Part considers the contours of that doctrine and concludes that petitioning immumity is not likely to protect union activity.

\section{The Genesis of Petitioning Immunity}

Immunity under the Sherinan Act for attempts to petition the government was first created by the Supreme Court in Eastern Railroad Presidents Conference v. Noerr Motor Freight, Inc. ${ }^{192}$ The Court reversed

negotiations). The court also assumed that the targeted firm would respond to the boycott by signing a collective bargaining agreement rather than by closing down or moving to another area. In the case of large, national contracting firms, a local umion is more likely to force the firm out of a given area than to cause it to change its national policy regarding the use of nonunion labor. Finally, as we note above, see supra Section III.A, raismg wage costs of nonumion contractors gives union contractors room to exploit market power, with potentially anticompetitive consequences.

192. 365 U.S. 127 (1961). The Court suggested three sources of this immurity: the "essential dissimilarity" between petitioning activity and traditional Sherman Act violations, id. at 136-37; the interest of a representative democracy in promoting petitioning activity before political bodies, id. at 137; and the "important constitutional questions" that would arise under the First Amendment right to petition if Congress were to restrict petitioning activity, id. at 137-38.

This ambignity in the origins of the doctrine, not resolved by the subsequent opimions in Umited Mine Workers v. Pennington, 381 U.S. 657 (1965) and Califormia Motor Transport Co. v. Trucking Unlimited, 404 U.S. 508 (1972), has led commentators to do vigorous battle over the origins and preeise scope of Noerr-Pennington immumity. See, e.g., AREedA \& HovenkaMP, supra note 124, I 201, at 14-16; Stephen Calkins, Developments in Antitrust and the First Amendment: The Disaggregation of Noerr, 57 ANTITRUST L.J. 327, 330-32, 346 n.96 (1988) (comparing statutory and constitutional basis for varying interpretations of Noerr); Daniel R. Fischel, Antitrust Liability for Attempts to Influence Government Action: The Basis and Limits of the Noerr-Pennington Doctrine, 45 U. CHr. L. Rev. 80, 81-84, 94-96 (1977) (Noerr exemption is properly limited to activity protected by constitutional right to petition); Milton Handler \& Richard A. De Sevo, The Noerr Doctrine and Its Sham Exception, 6 CARDozo L. REv. 1, 3-5 (1984) (approving Noerr as a workable rule grounded in constitutional intent); James D. Hurwitz, Abuse of Governmental Processes, the First Amendment, and the Boundaries of Noerr, 74 GEo. L.J. 65, 66 (1985) (interpreting Noerr as giving primacy to First Amendment considerations); Lawrence D. Bradley, Note, Noerr-Pennington Immunity from Antitrust Liability Under Clipper Exxpress v. Rocky Mountain Motor Tariff Bureau, Inc.: Replacing the Sham Exception with a Constitutional Analysis, 69 CORNELL L. REv. 1305 (1984) (asserting that Noerr is based squarely on the First Amendment); William L. Monts, III, 
a finding of antitrust liability against railroads that had conducted a pubhic-relations cainpaign designed to persuade state and local governments to pass laws restricting the trucking industry, a competitor in the shipping business. ${ }^{193}$ The Court noted that states would be immune from thc operation of the antitrust laws if they passed legislation that restricted competition. ${ }^{194}$ The Court then extended that immunity to "an atteinpt to persuade the legislature or the executive to take particular action with respect to a law that would produce a restraint or a monopoly."195

In United Mine Workers v. Pennington ${ }^{196}$ the Court extended Noerr immumity to a combination of union and employer groups that petitioned the Secretary of Labor to set a minimum "prevailing wage" in the coal industry, harming competitors that paid lower wages. The Court found the petitioner's anticompetitive purpose to be irrelevant. Even if the defendants' sole motivation for the petitioning activity was anticompetitive, the activity would be protected as long as the injury to competition resulted froin government rathcr than private action. ${ }^{197}$

Finally, in California Motor Transport Co. v. Trucking Unlimited ${ }^{198}$ the Court inodified the Noerr-Pennington doctrine in two important

Note, Allied Tube \& Conduit Corp. v. Indian Head, Inc.: An Emenging Conceptual Framework for Claims of Noerr Immunity, 41 S.C. L. REV. 633, 664-66 (1990) (Noerr is rooted in a construction of the Sherman Act and not solely in the First Amendment); Robert A. Zauzmer, Note, The Misapplication of the Noerr-Pennington Doctrine in Non-Antitrust Right to Petition Cases, 36 STAN. L. REV. 1243 (1984) (arguing that the right to petition should be treated like other First Amendment rights). Compare Bright v. Moss Ambulance Serv. Inc., 824 F.2d 819, 821 \& n.1 (10th Cir. 1987) (Noerr is an exemption to the antitrust laws based on the value to the government of receiving information) with In re Airport Car Rental Antitrust Litig., 521 F. Supp. 568, 575 (N.D. Cal. 1981) (Noerr governs cases that are outside the antitrust laws to begin with), aff'd, 693 F.2d 84 (9th Cir. 1982), cert. denied sub nom. Budget Rent-A-Car, Inc. v. Hertz Corp., 462 U.S. 1133 (1983) and with Occidental Petroleum Corp. v. Buttes Gas \& Oil Co., 331 F. Supp. 92, 108 (C.D. Cal. 1971) (First Amendinent is one basis for Noerr), aff'd, 461 F.2d 1261 (9th Cir.), cert. denied, 409 U.S. 950 (1972). See generally E. Thomas Sullivan, First Amendment Defenses in Antitrust Litigation, 46 Mo. L. REV. 517 (1981) (considering interactions between antitrust law and the First Amendinent other than Noerr).

We identify four distmet views of the source of the Noerr-Pennington doctrine: (1) it is compelled by the First Amendment; (2) it is a judicially created exception to the Sherman Act with a statutory basis; (3) it is a judicially created exception with a "constitutional core"; or (4) it merely describes conduct that does not fall within the Shernan Act in the first place. Resolution of this debate is not critical to the apphication of the doctrine we attempt here. Cf. Calkins, supra at 330-31 (discussing the importance of the doctrine's origins in determining its scope).

193. Noerr, 365 U.S. at 144-45.

194. Id. at 136. For a discussion of the so-called "state action" doetrine, see Parker v. Brown, 317 U.S. 341, 351-52 (1943) (Sherman Act did not intend to restrain official action by a state to control prices and output of private goods). See generally Einer R. Elhauge, The Scope of Antitrust Process, 104 HARv. L. REV. 667 (1991) (criticizing the state-action doetrine as a source of uncertainty and confusion for courts).

195. Noerr, 365 U.S. at 136.

196. 381 U.S. 657 (1965).

197. Id. at 669.

198. 404 U.S. 508 (1972). 
respects. First, the Court extended petitioning immunity to defendants who bring claims before courts or administrative agencies, ${ }^{199}$ as the unions here have done. Second, the Court held that petitioning will not be protected when "the alleged conspiracy is a nuere sham to cover what is actually nothing nore than an attenipt to interfere directly with the business relationships of a competitor.' "200

While courts and commentators have spent a great deal of time and energy since 1961 considering the precise limits of the doctrine, ${ }^{201}$ these

199. Id. at 510-11. The Court did note, however, that a number of practices protected when engaged in before the political branches might not be protected in administrative or judicial processes. Id. at 512-14.

200. Id. at 511 (einpbasis added) (quoting Eastern R.R. Presidents Conference v. Noerr Motor Freight, Inc., 365 U.S. 127, 144 (1961)). At first glance, the "mere sham" test might seein at odds with Pennington's holding that even petitions brought with the "sole purpose" of injuring competitors are protected. Pennington, 381 U.S. at 669. As we discuss below, the crucial distinction is that Pennington governs cases in which the government is being asked to restrain trade itself, while the sham exception applies when defendants restrain competition by the act of petitioumg itself, whether or not the government eventually acts. See California Motor, 404 U.S. at 511-12; infra notes 238-47 and accompanying text; see also Allied Tube \& Conduit Corp. v. Indian Head, Inc., 486 U.S. 492, 499-502 (1988) (Noerr immunity applies to a valid effort to influence governmental action; activities intended to affect a private standard-setting process did not qualify).

California Motor noted that the defendants' baseless lawsuits not only restrained trade by imposing costs and delay on a competitor, but actually rose to such a level that they in effect deried plaintiffs access to the courts. 404 U.S. at 513-15. In Franchise Rcalty Interstate Corp. v. San Francisco Local Joint Executive Board of Culinary Workers, 542 F.2d 1076 (9th Cir. 1976), cert. denied, 430 U.S. 940 (1977), the Ninth Circuit held that attempts to lobby and petition a governmental body, ü opposition to a grant of restaurant permits, were protected by the NoerrPennington doctrine unless the plaintiff could show that his own access had been barred. Id. at 1081-82. In recent cases, neither the Supreme Court nor lower courts have required a showing that access has been derried. See, eg., Vendo Co. v. Lektro-Vend Corp., 433 U.S. 623, 635 n.6 (1977) (plurality opinion) (fedcral court inay enjom commencement of additional state court proceedings if it concludes from the cause and outcome of the first proceeding that subsequent ones wonld be a repetitive sham and thus violate the antitrust laws); Otter Tail Power Co. v. United States, 410 U.S. 366,380 (1973) (cause of action under sham exception made out in absence of any allegation that access was barred); Sage Int'l, Ltd. v. Cadillac Gage Co., 507 F. Supp. 939, 946-48 (E.D. Mich. 1981) (no rigid requirement of pleading denial of access is necessary when the sham-litigation claim rests on a judicial action in which the antitrust plaimtiff prevailed); see also Thomas A. Balmer, Sham Litigation and the Antitrust Laws, 29 Bufralo L. REv. 39, 46-49 (1980) (examining the policy issues underlying the shain exception). The Ninth Circuit has simce declined to follow Franchise Realty. See Clipper Exxpress v. Rocky Mountain Motor Tariff Bureau, Inc., 690 F.2d 1240, 125859, 1258 n.27 (9th Cir. 1982), cert. denied, 459 U.S. 1227 (1983) (distinguishing Franchise Realty as involving a political rather than a purely adjudicatory body); Ernest W. Halm, Inc. v. Codding, 615 F.2d 830, $841 \mathrm{n} .14$ (9th Cir. 1980) (declining to follow Franchise Realty's requirement of denial of access).

201. For cases interpreting Noerr iu a variety of different fields, see infra notes 202-34 and accompanying text. In addition to the commentators cited supra note 192, sec generally BoRK, supra note 49, at 347-64 (outlining factors that should govern the application of Noerr in a variety of governmental contexts); Balmer, supra note 200, at 39 (examining sham exception and First Amendment policy issues in Noerr-Pennington cases); Michael W. Bien, Litigation as an Antitrust Violation: Conflict Between the First Amendment and the Sherman Act, 16 U.S.F. L. REv. 41 (1981) (concluding that First Amendment interests are sufficiently protected by the rigorous requirements for bringing an antitrust cause of action); Earl W. Kintner \& Joseph P. Bauer, Antitrust Exemptions for Private Requests for Governmental Action: A Critical Analysis of the Noerr-Pennington Doctrine, 
three cases estabhished the basic contours of petitioning immunity. Only in the last few years has the Suprene Court again taken up the difficult issues Noerr-Pennington presents.

\section{Allied Tube and Petitioning Immunity}

In 1988 the Supreme Court decided Allied Tube \& Conduit Corp. $v$. Indian Head, Inc. ${ }^{202}$ The plaintiffs challenged the defendant's attempts to influence safety standards by lobbying for the plaintiffs' product to be excluded froin a list of approved "safe" products. Although set by a private association, the standards routimely were approved by state and local governments. The defendant claimed Noerr immunity. The Supreme Court held tliat Noerr immunity did not apply. ${ }^{203}$ The Court's opimion is important for its description of the doctrine as a whole.

The Court identified three different categories of petitioning activity that might be proteeted, ${ }^{204}$ noting that " $[t]$ he scope of this protection depends ... on the source, context, and nature of the anticompetitive restraint at issue."205 First, anticompetitive restraints that result from valid governmental, as opposed to private, action "enjoy absolute immunity from antitrust liability."206 Second, when the private petitioning activity itself creates a restraint of trade, the immumity is narrower: "The restraint caumot form the basis for antitrust liability if it is 'nicidental' to a valid effort to influence governmental action."207 Finally, private action that "is not genuinely aimed at procuring favorable government action" falls within the shain exception to the exeinption and receives no immunity. $^{208}$

17 U.C. Davis L. REv. 549 (1984) (considering applicability of Noerr-Pennington to various governmental agencies); Lawrence A. Sullivan, Developments in the Noerr Doctrine, 56 ANTITRUST L.J. 361 (1987) (suggesting solutions to recurrent issues litigated under Noerr).

202. 486 U.S. 492 (1988).

203. Id. at 509-10.

204. Id. at 499-500. In fact, there is a fourth category as well: political boycotts. The Court has evaluated under the First Amendment political boycotts in which those conducting the boycott have no economic motivation, concluding that they raise no antitrust issue. Id. at 508-09; see NAACP v. Claiborne Hardware Co., 458 U.S. 886, 912-15 (1982) (state did not have power to prohibit peaceful, political boycott); Missouri v. National Org. for Women, Inc., 620 F.2d 1301, 1313-17 (8th Cir.) (efforts to influence legislature's action on Equal Rights Amendment by encouraging a convention boycott within the state were beyond scope and intent of the Sherman Act), cert. denied, 449 U.S. 842 (1980). But see International Longshoreman's Ass'n v. Allied Int'l, Inc., 456 U.S. 212 (1982) (an anoinalous case loolding umion liable for political boycott under the antitrust laws precisely because the union lad no economic interest in the outcone and the boycott imposed a leavy burden on neutral employers).

205. Allied Tube, 486 U.S. at 499.

206. Id.

207. Id.

208. Id. at 500 n.4. As noted below, this language conceals a number of complex issues concerning the application of the slam exception. See infra text accompanying notes 218-34.

In Allied Tube the Court concluded that the private standard-setting agency was not a government actor and that efforts to influence the setting of product standards did not qualify for 
Allied Tube is important for its discussion of limits on Noerr immunity. The Court rejected the view that the sham exception is the only limit. "We cannot agree with petitioner's absolutist position that the Noerr doctrine immunizes every concerted effort that is genuinely intended to influence governmental action."209 Instead, the validity of private restraints depends on whether their competitive effect or their political effect predominates. Thus, as the Court noted, a price-fixing agreement is not protected merely because the cartel seeks to have the government fix that price by law. ${ }^{210}$ Such an agreement wonld not be "incidental" to the attempt to influence the government; the anticompetitive effect is what is central to the restraint in that case.

\section{Unresolved Issues: Threats and the Sham Exception}

In addition to the confusion over the source of Noerr-Pennington immunity, ${ }^{211}$ four areas of uncertainty exist in the law of petitioning immunity that are relevant in evaluating the union litigation strategy. The first area concerns the extent to which the doctrine protects ancillary activity such as threats to sue; the other three concern the application of the shain exception.

Noerr immunity, by its ternns, applies to efforts to petition government agencies, including courts, even though such efforts restrain trade. A threat to sue or petition the government is not petitiouing activity, and therefore might seem not to be protected. ${ }^{212}$ The majority of courts and commentators vehemently reject this theory, however, ${ }^{213}$ describing it as

Noerr-Pennington immunity as incidental to a valid attempt to influence the government. 486 U.S. at 503-11.

209. Allied Tube, 486 U.S. at 503. Commentators discussing Allied Tube have agreed that this clarification is inportant. See, e.g., Calkins, supra note 192, at 335-38 (the Court's opinion "disaggregates" Noerr and gives the doctrine greater clarity); Monts, supra note 192, at 635 (Court's distinction between qualified and absolute immunity creates a new conceptual framework in which to evaluate Noerr clains).

210. Allied Tube, 486 U.S. at 504.

211. See supra note 192 .

212. Some courts have taken the view that threats to litigate are not protected by Noerr. See, e.g., CVD, Inc. v. Raytheon Co., 769 F.2d 842, 851 (1st Cir. 1985) (threats to litigate made in bad faith are unprotected and unay violate the antitrust laws), cert. denied, 475 U.S. 1016 (1986); Alexander v. National Farmers Org., 687 F.2d 1173, 1200 (8th Cir. 1982) (threatening hitigation against customers of conpetitor was in bad faith and unprotected); cert. denied, sub nom. National Farmers' Org., Inc. v. Associated Milk Producers Inc., 461 U.S. 937 (1983); Brownlee v. Applied Biosystems, Inc., 1989-1 Trade Cas. (CCH) \ 68,425, at 60,338 (N.D. Cal. 1989) (threats to institute sham litigation may constitute anticompetitive conduct sufficient to support antitrust claim); Oahu Gas Serv., Inc. v. Pacific Resources, Inc., 460 F. Supp. 1359, 1386 (D. Haw. 1978) (threats of lawsuit against potential customers of competitors were not protected, although threats to the competitors themselves would be protected).

213. See, eg., Coastal States Mktg., Inc. v. Hunt, 694 F.2d 1358, 1367 (5tl Cir. 1983) (petitioning immunity protects acts that are reasonable and normally attendant to litigation); Outboard Marine Corp. v. Pezetel, 474 F. Supp. 168, 174 (D. Del. 1979) (threats to resort to courts, without inore, are protected); Pennwalt Corp. v. Zenith Labs., Inc., 472 F. Supp. 413, 424 (E.D. 
“anomalous"214 and "absurd"215 to protect actual lawsuits but not the communications and threats normally incidental to theni.

The latter position seems more sound, but with an important caveat. Threats alone can in no way be designed to influence the governnient to act; they will either have no effect or will persuade a private party to act. Thus, the rule of Allied Tube protects threats only if they are incidental to a valid lawsuit. ${ }^{216}$ If that suit is a sham, of course, threats to instigate it should not be protected. ${ }^{217}$ Beyond that, moreover, if the threats are designed to achieve an anticompetitive purpose independent of the ostensible goal of the lawsuit, they are clearly not incidental to the lawsuit. A union litigating to enforce the environmental laws but using threats to acquire a labor monopoly is probably engaged in such unrelated threats.

A second issue that has divided the lower courts is whether litigation that is successful in whole or im part can nonetleless constitute a sham. ${ }^{218}$ While the Court has implicitly resolved the issue by finding a sham although the hitigation liad been partially successful, ${ }^{219}$ it lias never spoken directly on the question. ${ }^{220}$ This question is bound up with the

Mich. 1979) (attempt to petition protected so long as not a sham); Clairol v. Boston Discount Ctr., Inc., 1976-2 Trade Cas. (CCH) I 61,108, at 70,021 (E.D. Mich.) (letter threatening boycott protected), aff'd, 608 F.2d 1114 (6th Cir. 1976); AREEDA \& HovENKAMP, supra note 124, If 203.5, at 58-60 (protection of right to sue without protection of threats would not make sense).

214. AREEDA \& HOVENKaMP, supra note 124, $\Uparrow 203.5$, at 58.

215. Coastal States, 694 F.2d at 1367.

216. See supra text accompanying note 207.

217. In this respect, we agrec with those cases cited supra note 212 that hold that threats incidental to sham litigation are unprotected.

218. Compare Boulware v. Nevada, Dep't of Human Resources, 960 F.2d 793, 797-98 (9th Cir. 1992); Omni Outdoor Advertising, Inc. v. Columbia Outdoor Advertising, Inc., 891 F.2d 1127, 1139 (4th Cir. 1989), rev'd on other grounds sub nom. City of Columbia v. Omni Outdoor Advertising, Inc., 111 S. Ct. 1344 (1991); Aydin Corp. v. Loral Corp., 718 F.2d 897, 903 (9th Cir. 1983); GripPak, Inc. v. Illinois Tool Works, Inc., 694 F.2d 466, 471-72 (7th Cir. 1982), cert. denied, 461 U.S. 958 (1983); and Clipper Exxpress v. Rocky Mountain Motor Tariff Bureau, Inc., 690 F.2d 1240, $1255 \mathrm{n} .22$ (9th Cir. 1982), cert. denied, 459 U.S. 1227 (1983) (all holding or assuming that litigation can be a sham regardless of the outcome) with Columbia Pictures Indus., Inc. v. Redd Horne, Inc., 749 F.2d 154, 161 (3d Cir. 1984); Omni Resource Dev. Corp. v. Conoco, Inc., 739 F.2d 1412, 1414 (9th Cir. 1984); Coastal States, 694 F.2d at 1372 \& n.45; Taylor Drug Stores, Inc. v. Associated Dry Goods Corp., 560 F.2d 211, 213 (6th Cir. 1977); and St. Joseph's Hosp., Inc. v. Hospital Auth. of Am., 620 F. Supp. 814, 829 \& n.16 (S.D. Ga. 1985), vacated, 795 F.2d 948 (11th Cir. 1986) (all holding or assuming that successful litigation cannot be a sham).

219. In California Motor Transport Co. v. Trucking Unlimited, 404 U.S. 508, 515-16 (1972), the case in which the Court first apphied the sham exception, a majority of the antitrust offender's claims were in fact successful. See Trucking Unlimited v. California Motor Transp. Co., 1967 Trade Cas. (CCH) I 72,298, at 84,744 (N.D. Cal. 1967) (21 of 40 clains were ultinately resolved in plaintiff's favor).

220. The Supreme Court recently considered a case involving successful petitioning in City of Columbia v. Omni Outdoor Advertising, 111 S. Ct. 1344 (1991). The Court resolved the case on other grounds, however, leaving open the question of whether successful petitioning could constitute a sham. In Omni Outdoor, Omni alleged that the City of Columbia and competitor Columbia Outdoor had conspired to pass zoning ordinances that limited Onni's ability to conipete. The Court leld that the city was immune fron antitrust liability under the state-action doctrine, even though it 
issue of how courts should test sham motivations. ${ }^{221}$ For the reasons stated below, we conclude that hitigation should not receive immunity simply because it is successful, if its motivation and effect are predominantly anticompetitive. ${ }^{222}$

The third unresolved issue is whether a single sham lawsuit is sufficient to imvoke the sham exception or whether the sham exception requires a pattern of anticompetitive hitigation. Again, lower courts have spht on this issue, with a decided majority coming out in favor of hability for single sham suits. ${ }^{223}$ The Supreme Court considered this issue without reaching a decision in Vendo Co. v. Lektro-Vend Corp. ${ }^{224}$ In that case, four dissentimg Justices concluded that a single suit could fall within the sham exception. ${ }^{225}$ Two concurring Justices disagreed and would require a pattern of baseless litigation before invoking the antitrust laws. ${ }^{226}$ The plurality did not reach the sham-litigation issue but indicated in a footnote that a single suit could be sufficient to enjoin further hitigation under the antitrust laws. ${ }^{227}$ Thus, four Justices, and perhaps a majority, would have followed the majority of lower courts and applied the sham exception to simgle suits in some circunistances.

We agree with Professors Areeda and Hovenkainp that a single suit can trigger the sham exception in certain circumstances. As they note:

was alleged to have "conspired" with Columbia Outdoor to restrain competition. Id. at 1350-53. The Court also found Columbia Outdoor inmune from antitrust hability under Noerr because Omni was hurt by the outcome of governmental action rather than by the petitioning process itself. Id. at 1353-56. Thus, the Court's holding is consistent with Allied Tube. Because the Court reversed on these grounds, it did not consider whether successful petitioning could nonetheless constitute a sham.

221. See infra notes 229-34 and accompanying text.

222. We therefore disagree with Professors Areeda and Hovenkamp, who take the position that successful suits are protected. See AREeDA \& HovenKamp, supra note 124, ๆ 203.1d, at 26-30. While they call their position "merely a strong presumption, rather than a categorical rule," their exceptions all have to do with abuse of process withm the lawsuit itself (misuse of discovery, perjury, or conspiracy with the tribunal). See id. at 30.

223. See Balmer, supra note 200 , at 55 (stating that the lower courts disagree on the single sham suit issue and are likely to continue to differ). Compare Boulware v. Nevada, Dep't of Human Resources, 960 F.2d 793, 797-98 (9th Cir. 1992); Rickards v. Canine Eye Registration Found., 783 F.2d 1329, 1334 (9th Cir.), cert denied, 419 U.S. 851 (1986); MCI Communications Corp. v. American Tel. and Tel. Co., 708 F.2d 1081, 1154-55 (7th Cir.), cert denied, 464 U.S. 891 (1983); Feminist Women's Health Ctr., Inc. v. Mohammed, 586 F.2d 530, 543 n.6 (5th Cir. 1978), cert. denied sub nom. Palmer v. Feminist Women's Health Ctr., Inc., 444 U.S. 924 (1979); and Colorado Petroleum Marketers Ass'n v. Southland Corp., 476 F. Supp. 373, 378-79 (D. Colo. 1979) (all holding or assuming that a simgle suit can be a sham) with Loctite Corp. v. Fel-Pro, Inc., 1978-2 Trade Cas. (CCH) If 62,204, at 75,358 (N.D. Ill. 1978), aff'd, 667 F.2d 577 (7th Cir. 1981) and Mountain Grove Cemetery Ass'n v. Norwalk Vault Co., 428 F. Supp. 951, 955-56 (D. Conn. 1977) (both holding that a single suit cannot be a sham).

224. 433 U.S. 623 (1977) (plurality opinion).

225. Id. at 661-62 (Stevens, J., dissenting). Indeed, they concluded that a single suit could itself violate the antitrust laws. $I d$.

226. Id. at 644-45 (Blackmun, J., concurring).

227. Id. at 635-36 n.6 (plurality opinion). 
"It is not the number of lawsuits or protests that determines the existence of a sham but the legitimacy of the antitrust defendant's actions."228 This question merges into the final and we think most important unresolved issue: how courts are to test anticompetitive motivations.

There are two basic dimensions to the question of how to test allegedly sham litigation: (1) whether baselessness should be tested subjectively or objectively; and (2) whether anticompetitive motivation must merely exist, must predominate, or must be the exclusive motivation. Courts have taken each position. ${ }^{229}$ We believe that this question is answered in large measure by Allied Tube. ${ }^{230}$ In that case the Court made two statements on sham litigation that present a consistent view of the purpose of the sham exception. In setting forth the contours of Noerr immuuity, the Court noted that "[o]f course, in whatever forum, private action that is not genuinely aimed at procuring favorable government action is a mere sham."231 Later in the opinion the Court criticized the Ninth Circuit for concluding that the sham exception extends to a defendant who " 'genuinely seeks to achieve his governmental result, but

228. AREEDA \& HOVENKAMP, supra note 124, I $203.1 \mathrm{e}$, at 32.

229. For support of the objective standard, sec Columbia Pictures Indus., Inc. v. Professional Real Estate Investors, Inc., 944 F.2d 1525, 1532 \& n.10 (9th Cir. 1991) (motive is irrelevant if suit is based on probable cause), cert granted, 112 S. Ct. 1557 (1992); Razorback Ready Mix Concrete Co. v. Weaver, 761 F.2d 484, 487-88 (8th Cir. 1985) (court ignored defendant's motives in concluding that a single suit does not give rise to a cause of action under the antitrust laws "absent allegations that the lawsuit involves serious misconduct"); Alexander v. National Farmers Org., 687 F.2d 1173, 1200-03 (8th Cir. 1982) (court disregarded evidence of intent in conducting sham analysis); cert. denied sub nom. National Farmers' Org., Inc. v. Associated Milk Producers Inc., 461 U.S. 937 (1983); AREEDA \& HOVENKAMP, supra note 124, I 203.1c, at 23-26. For support of the subjective standard, see In re Burlington N., Inc., 822 F.2d 518, 528 (5th Cir. 1987) ("It must be shown that the desire for rehef was a significant factor underlying the actual bringing and prosecution of the suit. This requires an examination of the hitigant's intent."), cert. denied sub nom. Union Pac. R.R. Co. v. Energy Transp. Sys., Inc., 484 U.S. 1007 (1988); GTE Data Servs., Inc. v. Electronic Data Sys. Corp., 717 F. Supp. 1487, 1490-91 (M.D. Fla. 1989) (sham exception is applied looking at htigant's intent); Barq's, Inc. v. Barq's Beverages, Inc., 677 F. Supp. 449, $452-53$ (E.D. La. 1987) (looking to the specific facts of the case, the defendant's conduct was "in aceordance with the spirit of the law" and therefore exempt from the antitrust laws).

Courts have also sphit over how important the anticompetitive purpose must be as a motivating factor. See Bien, supra note 201, at 92 (noting this division). On the one hand, the Sixth Circuit has concluded that a suit is a sham only if the plaintiff's sole intent is to harass the defendants. Westmac, Inc. v. Smith, 797 F.2d 313 (6th Cir. 1986) (sham exception is not invoked merely by a finding that hitigant's "principle [sic] purpose" was anticompetitive; litigation must be instituted "without concern for obtaining a favorable judgment"), cert. denied, 479 U.S. 1035 (1987). On the other hand, Judge Easterbrook makes a coinpelling case that any anticompetitive motivation ought to suffice to inake a suit a sham. Premier Elec. Constr. Co. v. National Elec. Contractors Ass'n, 814 F.2d 358, 376 (7th Cir. 1987). The Fifth Circuit has taken an interinediate position, concluding that the deeision to litigate must be "significantly motivated be a genuine desire for judicial relief" to warrant protection. In re Burlington, 822 F.2d at 528.

230. Allied Tube \& Conduit Corp. v. Indian Head, Inc., 486 U.S. 492 (1988).

231. Id. at 500 n.4. 
does so through improper means." "232 The Court argued that "[s]uch a use of the word 'sham' distorts its meaning and bears little relation to the sham exception." 233

The Court seems to have intended by these statements to reject both aspects of the objective test. The objective test would find an objectively baseless suit undertaken in subjective good faith to be a sham. Similarly, the objective test would find no sham when reasonably grounded litigation is undertaken in subjective bad faith. In Allied Tube, however, the Court found that genuine belief is sufficient to invoke Noerr immunity but that objective validity is not. ${ }^{234}$

The subjective test is therefore the appropriate one-subjective good faith is both necessary and sufficient for protection. The question of how to test motivation remains. While this is a difficult question, the substantial-factor test articulated by the Fifth Circuit most closely approximates the Court's "genuine behef" standard. ${ }^{235}$ Judge Easterbrook's approach in Premier Electrical Construction Co. v. National Electrical Contractors Assocation, ${ }^{236}$ while economically sound, would punish even those who do intend to influence the government, and we think this test is at odds with Allied Tube. Similarly, the Sixth Circuit rule ${ }^{237}$ would protect not ouly a nuniber of suits motivated almost exclusively by anticoinpetitive mterests, but would, in combimation with the requirement that subjective intent be shown, make it almost impossible to prove a sham as a practical matter.

\section{B. Applications}

Each of these unresolved issues has some bearing on the application of Noerr-Pennington immumity to the union hitigation strategy considered here. Unions have threatened to bring and, in substantially fewer cases, actually have brought suits and administrative and regulatory coniplaints

232. Id. at 508 n.10 (quoting Sessions Tank Liners, Inc. v. Joor Mfg., Inc., 827 F.2d 458, 465 n.5 (9th Cir. 1987)).

233. Id.

234. This ought to decide the issue of successful lawsuits in favor of the Fourth Circuit's decision in Omni Outdoor Advertising, Inc. v. Columbia Outdoor Advertising, Inc., 891 F.2d 1127, 1139 (4th Cir. 1989), rev'd on other grounds sub́ nom. City of Columbia v. Omni Outdoor Advertising, Inc., 111 S. Ct. 1344 (1991). In Omni Outdoor the Fourth Circuit concluded that even though plaintiff's suits were successful, they could nonetheless be part of a pattern of sham litigation if they were brought with intent to harass. As noted above, the Supreme Court did not decide this issue when it heard the case. See City of Columbia v. Omni Outdoor Advertising, 111 S. Ct. 1344 (1991).

235. In re Burlington N., Inc., 822 F.2d 518, 528 (5th Cir. 1987), cert. denied sub nom. Union Pac. R.R. Co. v. Energy Transp. Systems, Inc., 484 U.S. 1007 (1988); see also supra note 229.

236. 814 F.2d 358, 376 (7th Cir. 1987); see also supra note 229.

237. Westmac, Inc v. Smith, 797 F.2d 313, 318 (6th Cir. 1986), cert. denied, 479 U.S. 1035 (1987); see also supra note 229. 
that challenge construction projects. ${ }^{238}$ Nonetheless, unions use the threat of this (primarily environmental) litigation not to get environmental concessions from job owners, but rather to change the owners' policy towards the use of umion labor. The goals of the union threats are thus unrelated to the subject of the threatened hitigation. We think such threats are unprotected on two grounds.

First, Noerr simply may not apply to such suits. As noted above, 239 threats themselves are not petitioning activity and are protected only because they are normally mcidental to petitionimg activity. Here, because such threats are unrelated to petitioning activity-im that they are aimed at a different goal-they do not advance that activity and are not deserving of protection. The Court in Noerr seenied to recognize this. In overturning the district court's conclusion that the defendants' purpose was to hurt competition, the Court exphicitly noted that "[t]here are no specific findings that the railroads attempted directly to persuade anyone not to deal with the truckers."240 If there is evidence that such threats were made, the courts should not protect those threats.

Second, even if the union actually pursues a lawsuit, the anticompetitive effects predominate and are not merely "imcidental" to valid petitioning activity. The union's threats associated with its pattern of hitigation themselves restrict competition. This is not, therefore, a case in which it is governmental action that threatens competition. ${ }^{241}$ The union's threats hurt conipetition by coercing job owners, whether or not the litigation ultimately is successful. ${ }^{242}$ It therefore should be tested under Allied Tube's "mcidental to valid petitionmg activity" standard. Threats aimed at coercing agreements to use union labor are in no sense necessary to environinental lawsuits, and they should not be protected.

Even if the union's conduct falls within the boundaries of NoerrPennington immuinty, that conduct could nonetheless be unprotected because of the shan1 exception. ${ }^{243}$ The union litigation strategy as a

238. See supra Section II.A.

239. See supra text accompanying notes 212-17.

240. Eastern R.R. Presidents Conference v. Noerr Motor Freight, Inc., 365 U.S. 127, 142 (1961).

241. See Allied Tube \& Conduit Corp. v. Indian Head, Inc., 486 U.S. 492, 500-02 (1988) (distinguishing competitive restraints imposed by the government froin those that result from private petitioning activity).

242. That denial of permits or injunctions against building a project might restrict competition betwecn job owners in the building lease/sale industry should be of no relevance. The anticompetitive effect of petitioning by the unions operates against a different target-the nonunion contractors. It would be anomalous to protect petitioning that injures competition in one market because the petitioning, if successful, will cause the government to restrict coinpetition in a different inarket.

243. Petitioning before regulatory bodies can fall within the sham exception, just as lawsuits can. California Motor Transp. Co. v. Trucking Unlinited, 404 U.S. 508, 513 (1972) (holding that a pattern of baseless, repetitive claims in the administrative process is not inmune from antitrust 
whole involves multiple suits against various job owners, ${ }^{244}$ which taken together constitute a "pattern" of baseless litigation. ${ }^{245}$ The sliain exception might protect tliose suits that are ultimately successful. ${ }^{246}$ Even if the Court eventually concludes that successful suits cannot be sliams, however, that merely protects the unions from antitrust liability for those suits. There is no mdication tliat the Court would go a substantial step furtler and hold that a single successful suit will immunize all future conduct by the union against different parties. Sucli a lolding would be inconsistent with the reasoning of Allied Tube, ${ }^{247}$ and illogical as well.

Finally, the anticonıpetitive motivations of the union seen to be established by the content (and success) of their threats, which were uurelated to the subject matter of their lawsuits. The subjective intent of any union pursuing such a litigation strategy will, of course, be a question of fact. ${ }^{248}$ Nonetheless, the court in Clipper Exxpress v. Rocky Mountain Motor Tariff Bureau was correct im observing tliat "autoinatic" lawsuits filed "without regard to merit or possible success," but on the basis of another criterion, such as the use of merit-sliop contractors, are likely to be shams. ${ }^{249}$ While it probably goes too far to argue that sucl suits "fall within the sliain exception as a matter of law,"250 sucli a practice is certainly strong evidence of anticompetitive inotivation and thus of shain litigation.

In sliort, the union's litigation, mucli less its threats, will likely not receive Noerr-Pennington protection, particularly given the Court's recent efforts to limit petitioning immunity ${ }^{251}$ and its policy of construing narrowly exeinptions froin the antitrust laws. ${ }^{252}$ Even if union suits were

laws); see also Greenwood Util. Comm'n v. Mississippi Power Co., 751 F.2d 1484, 1498 n.9 (5th Cir. 1985) (an action instituted against a rival before a regulatory agency, motivated by a desire to force that rival to defend against the action rather than by the hope of a favorable agency ruling, is not bona fide petitioning activity); Litton Sys., Inc. v. American Tel. and Tel. Co., 700 F.2d 785, 811-12 (2d Cir. 1983) (AT\&T's petitioning before the FCC in the hope of delaying, rather than influencing, governinent action "amounted to the sort of abuse of the legislative process that falls within the Noerr-Pennington sham exception"), cert. denied, 464 U.S. 1073 (1984).

244. See supra text accoinpanying notes 7-19. Each job owner may be sued only once, but the Court has never required that a "pattern" of baseless suits all be directed at the same party. See, e.g., Otter Tail Power Co. v. United States, 410 U.S. 366, 379-80 (1973) (lawsuits brought against four different parties inay be a "pattern" of suits within the sham exception).

245. For a discussion of this question, see supra text accompanying notes 223-28.

246. See supra notes $218-22$ and accompanying text.

247. See supra notes 202-10 and aceompanying text.

248. Clipper Exxpress v. Rocky Mountain Motor Tariff Bureau, Inc., 690 F.2d 1240, 1253 (9th Cir. 1982) ("Whether soniething is a genuine effort to influence government action, or a mere sham, is a question of fact."), cert. denied, 459 U.S. 1227 (1983).

249. Id. at 1254.

250. Id.

251. See supra text accompanying notes 202-10 (discussion of Allied Tube).

252. Union Labor Life Ins. Co. v. Pireno, 458 U.S. 119, 126 (1982) ("[O]ur precedents consistently hold that exemptions froin the antitrust laws unust be construed narrowly."); Wiley, 
protected, however, the evidence of the union's motivation and its attempts to coerce market participants might be used to prove a separate antitrust claim.

VI

\section{CONCLUSION}

Umion activity such as that undertaken by the building-trades umions in northern California poses a threat to conipetition and is amenable to suit under the antitrust laws. While the union activity does not fit precisely into any traditional antitrust category, it is best characterized as an attempt to monopolize or a group boycott. The labor exemption and Noerr-Pennington immunity are hurdles, but neither should prove an insurmountable barrier to a successful challenge to the union litigation strategy.

supra note 152, at 713 n.1 (stating that "the Court disclaims its authority to create antitrust exemptions"). 



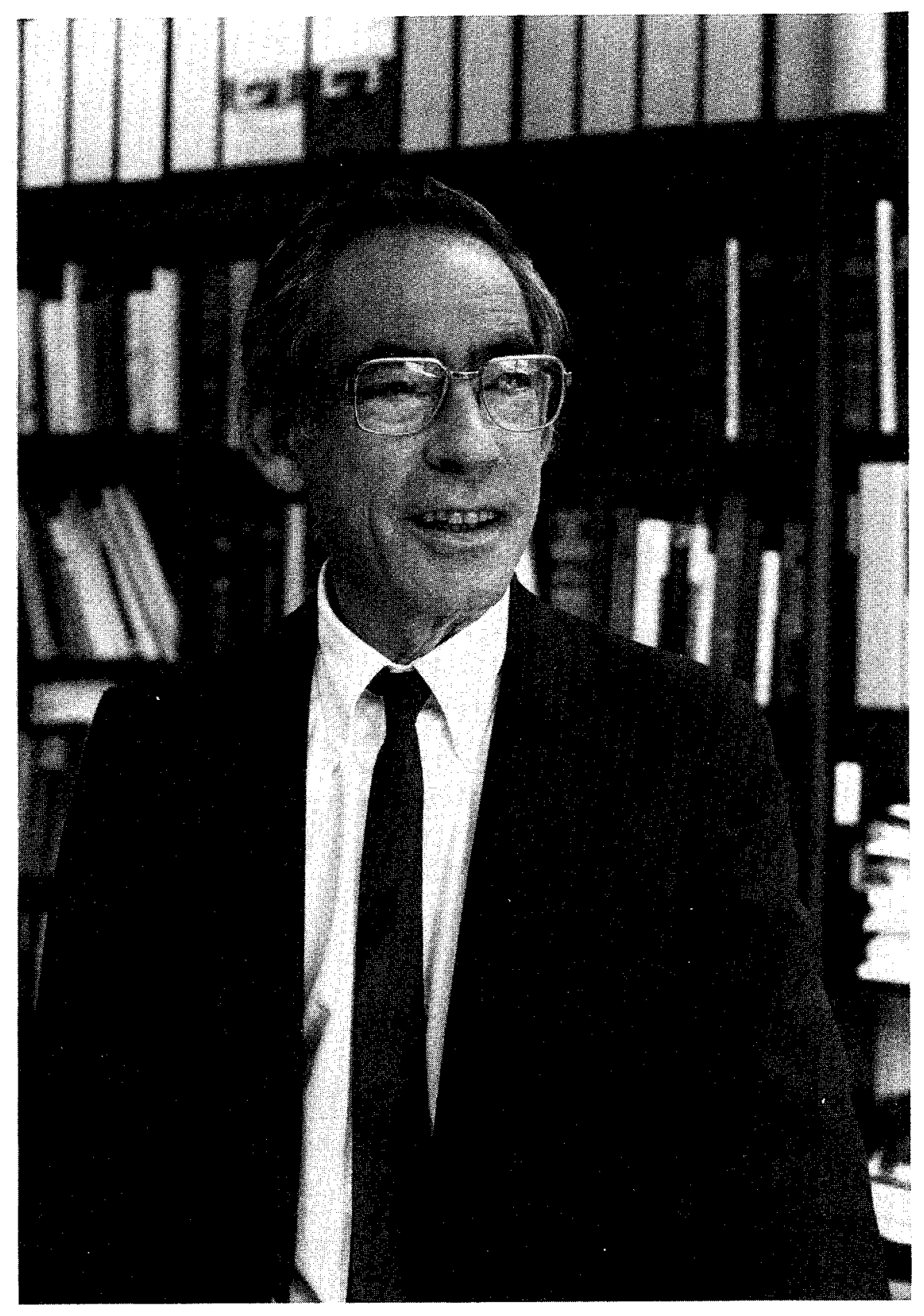

Preble Stolz 